Prepared for the U.S. Department of Energy

under Contract DE-AC05-76RL01830

\title{
Radionuclide Retention in Concrete Waste Forms
}

\author{
SV Mattigod \\ CC Bovaird \\ DM Wellman \\ MI Wood
}

September 2010

\section{Pacific Northwest}

NATIONAL LABORATORY

Proudly Operated by Battelle Since 1965 


\title{
DISCLAIMER
}

This report was prepared as an account of work sponsored by an agency of the United States Government. Neither the United States Government nor any agency thereof, nor Battelle Memorial Institute, nor any of their employees, makes any warranty, express or implied, or assumes any legal liability or responsibility for the accuracy, completeness, or usefulness of any information, apparatus, product, or process disclosed, or represents that its use would not infringe privately owned rights. Reference herein to any specific commercial product, process, or service by trade name, trademark, manufacturer, or otherwise does not necessarily constitute or imply its endorsement, recommendation, or favoring by the United States Government or any agency thereof, or Battelle Memorial Institute. The views and opinions of authors expressed herein do not necessarily state or reflect those of the United States Government or any agency thereof.

\author{
PACIFIC NORTHWEST NATIONAL LABORATORY \\ operated by \\ BATTELLE \\ for the \\ UNITED STATES DEPARTMENT OF ENERGY \\ under Contract DE-AC05-76RL01830
}

Printed in the United States of America

\author{
Available to DOE and DOE contractors from the \\ Office of Scientific and Technical Information, \\ P.O. Box 62, Oak Ridge, TN 37831-0062; \\ ph: (865) 576-8401 \\ fax: (865) 576-5728 \\ email: reports@adonis.osti.gov
}

\begin{abstract}
Available to the public from the National Technical Information Service, U.S. Department of Commerce, 5285 Port Royal Rd., Springfield, VA 22161 ph: (800) 553-6847 fax: (703) 605-6900

email: orders@ntis.fedworld.gov

online ordering: http://www.ntis.gov/ordering.htm
\end{abstract}




\title{
Radionuclide Retention in Concrete Waste Forms
}

\author{
SV Mattigod \\ CC Bovaird \\ DM Wellman \\ MI Wood
}

September 2010

Prepared for

The U.S. Department of Energy

Under Contract DE-AC05-76RL01830

Pacific Northwest National Laboratory

Richland, Washington 99352 



\section{Summary}

Assessing long-term performance of Category 3 waste cement grouts for radionuclide encasement requires knowledge of the radionuclide-cement interactions and mechanisms of retention (i.e., sorption or precipitation); the mechanism of contaminant release; the significance of contaminant release pathways; how waste form performance is affected by the full range of environmental conditions within the disposal facility; the process of waste form aging under conditions that are representative of processes occurring in response to changing environmental conditions within the disposal facility; the effect of waste form aging on chemical, physical, and radiological properties; and the associated impact on contaminant release. This knowledge will enable accurate prediction of radionuclide fate when the waste forms come in contact with groundwater. The information presented in the report provides data that 1) quantify radionuclide retention within concrete waste form materials similar to those used to encapsulate waste in the Low-Level Waste Burial Grounds (LLBG); 2) measure the effect of concrete waste form properties

likely to influence radionuclide migration; and 3) quantify the stability of uranium-bearing solid phases of limited solubility in concrete. 



\section{Acknowledgments}

Funding for this project was provided by CH2M HILL Plateau Remediation Company (CHPRC) (Marc Wood). The authors thank Kent Parker for preparing concrete-sediment half-cell tests; Kenton

Rod for sectioning the concrete monoliths and conducting water extractions; and Steven Baum and Keith Geizsler for conducting inductively coupled plasma optical emission spectrometry (ICP-OES) and ICP-mass spectrometry (ICP-MS) analyses, respectively. 



\section{Acronyms and Abbreviations}

\begin{tabular}{|c|c|}
\hline $\mathrm{Al}$ & aluminum \\
\hline BFS & blast furnace slag \\
\hline $\mathrm{Ca}$ & calcium \\
\hline CHPRC & CH2M HILL Plateau Remediation Company \\
\hline EDS & energy dispersive spectrometer \\
\hline EXAFS & extended absorption X-ray fine structure \\
\hline $\mathrm{Fe}$ & iron \\
\hline FY & fiscal year(s) \\
\hline HNO3 & nitric acid \\
\hline I & iodine \\
\hline ICP-MS & inductively coupled plasma-mass spectrometry \\
\hline ICP-OES & inductively coupled plasma-optical emission spectrometry \\
\hline $\mathrm{L}$ & limestone \\
\hline LER & licensee event reports \\
\hline LLBG & low-level waste burial grounds \\
\hline $\mathrm{Mg}$ & magnesium \\
\hline $\mathrm{Na}$ & sodium \\
\hline $\mathrm{OPC}$ & ordinary Portland cement \\
\hline OPC/BFS/L & ordinary Portland cement/ blast furnace slag/limestone \\
\hline$P$ & phosphorus \\
\hline PA & performance assessment \\
\hline PUF & pressurized unsaturated flow \\
\hline PVC & polyvinyl chloride \\
\hline $\operatorname{Re}$ & rhenium \\
\hline $\mathrm{Se}$ & selenium \\
\hline SEM & scanning electron microscopy \\
\hline SEM-EDS & scanning electron microscopy/energy dispersive spectrometer \\
\hline $\mathrm{Si}$ & silicon \\
\hline SRPC & sulfate-resistant Portland cement \\
\hline SSRL & Stanford Synchrotron Radiation Laboratory \\
\hline Tc & technetium \\
\hline $\mathrm{U}(\mathrm{VI})$ & uranium (VI) \\
\hline wt & weight \\
\hline $\mathrm{XRD}$ & $\mathrm{X}$-ray diffraction \\
\hline
\end{tabular}





\section{Contents}

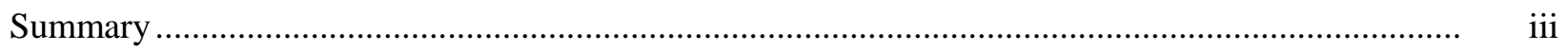

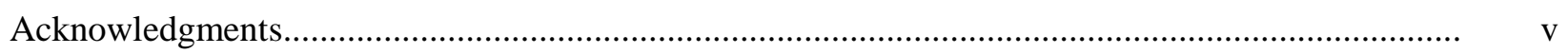

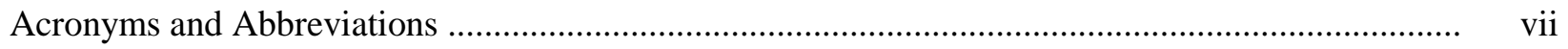

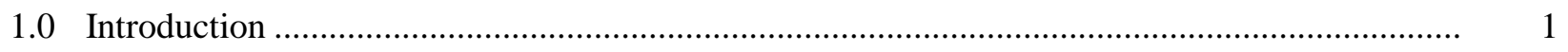

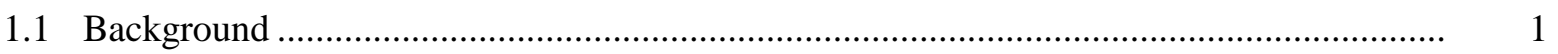

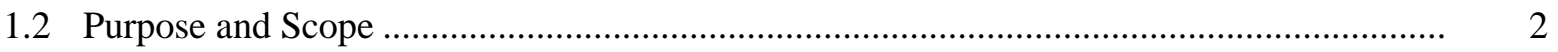

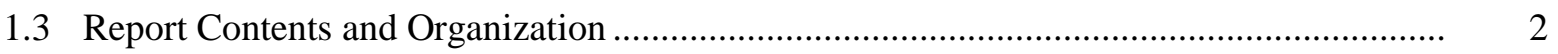

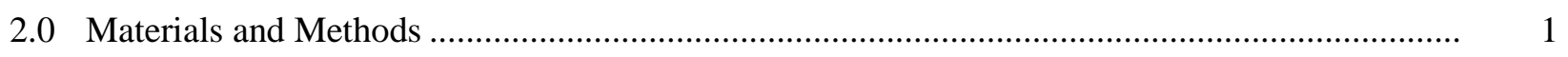

2.1 Specified Concrete Composition for Encasement ............................................................. 1

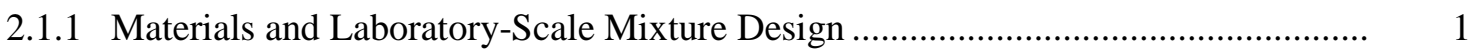

2.2 Concrete Mix and Specimen Preparation ......................................................................... 2

2.3 Fractured Concrete-Sediment Half-Cells Spiked with Iodine and Technetium .................. 2

2.4 Half-Cell Preparation, Testing, and Analysis................................................................ 3

2.5 Effective Diffusion Coefficient Calculations ................................................................... 4

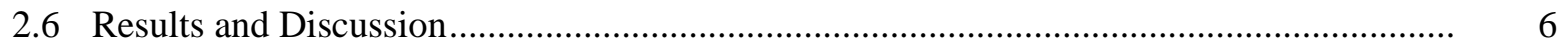

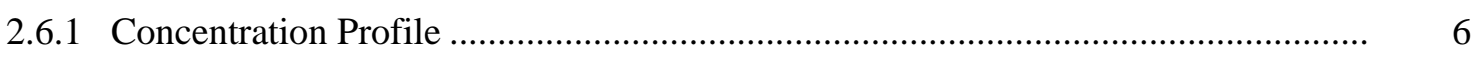

2.7 Probit Analysis Results and Discussion ......................................................................... 11

3.0 Pressurized Unsaturated Flow (PUF) Tests Selected Concrete Waste Forms to Assess the Long-term Stability under Hanford Vadose Zone Conditions................................................. 1

4.0 Solubility of Uranium in Concrete Waste Forms and Hanford Vadose Zone Sediments ............ 1

4.1 Extended X-Ray Absorption Fine Structure Spectroscopy ............................................... 2

4.2 Recommendations on Solubility of Uranium in Concrete Waste Forms and Hanford Vadose Zone Sediments ............................................................................................. 5

5.0 Comprehensive Report on All the Diffusion Work Conducted Over the Project Life Period...... 1

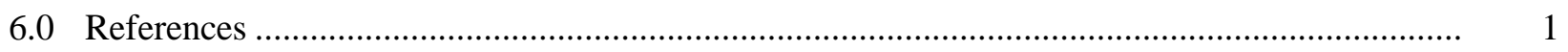




\section{Figures}

2.1 Mechanism for Sediment Sampling from a Concrete-Sediment Diffusion Half-Cell and Sediment Sampling from a Diffusion Half-Cell

2.2 Tc Soil Concentration Profiles for Carbonated and Non-Carbonated Cores 4\% Soil Moisture, $0 \% \mathrm{Fe}, 4 \%$ Soil Moisture, 4\% Fe, 4\% Soil Moisture, $8 \% \mathrm{Fe}, 4 \%$ Soil Moisture, $12 \% \mathrm{Fe}$

2.3 Concrete Half-Cell Concentration Profiles as a Function of Iron Content Tc Concentration for Uncarbonated Concrete at 4\% Soil Moisture, Tc Concentration for Carbonated Concrete at $4 \%$ Soil Moisture

2.4 Tc Soil Concentration Profiles for Carbonated and Non-Carbonated Cores 4\% Soil Moisture, $0 \% \mathrm{Fe}, 4 \%$ Soil Moisture, 4\% Fe, 4\% Soil Moisture, $8 \% \mathrm{Fe}, 4 \%$ Soil Moisture, $12 \% \mathrm{Fe}$

2.5 Concrete Half-Cell Concentration Profiles as a Function of Iron Content Tc Concentration for Uncarbonated Concrete at 4\% Soil Moisture, Tc Concentration for Carbonated Concrete at $4 \%$ Soil Moisture

2.6 Probit Analysis of FY 2010 Tc Cores Tc-C-10-5-0-101, Tc-C-10-5-0-102, Tc-C-10-5-4-105, Tc-C-10-5-4-106

2.7 Probit Analysis of FY 2010 Tc Cores Tc-C-10-5-8-107, Tc-C-10-5-8-108, Tc-C-10-5-12-110, Tc-C-10-5-12-111

3.1 Photo of PUF Column Assembly.

3.2 $\log _{10}$ Concentration of Elements, in $\mu \mathrm{g} / \mathrm{L}$, Released From the Concrete Coupon PUF Column Measured in the Effluent Solutions As a Function of Pore Volume

4.1 EXAFS of 3.5 and 1 Year Autunite Solubility Tests Autunite Mineral, Harwell Reacted Autunite After 3.5 Months, Harwell Reacted Autunite After 1 Year, BFS Reacted Autunite After 3.5 Months, and BFS Reacted Autunite After 1 Year....

4.2 EXAFS of 3.5 Month Reacted Autunite Solubility Tests Autunite Mineral, SRPC Reacted Autunite After 3.5 Months, Harwell Reacted Autunite After 3.5 Months, and BFS Reacted Autunite After 3.5 Months

4.3 EXAFS of 3.5 Month Reacted Soddyite Solubility Tests Soddyite Mineral, Harwell Reacted Soddyite After 3.5 Months, OPC/L Reacted Soddyite After 3.5 Months, BFS Reacted Soddyite After 3.5 Months, and Uranophane Mineral. 


\section{Tables}

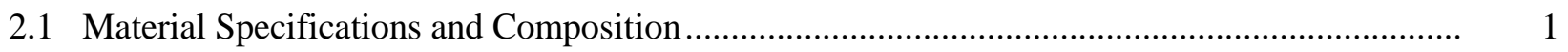

2.2 Laboratory-Scale Material Specification and Composition...................................................... 2

2.3 Characteristics of Concrete Specimens Used in Concrete-Soil Half-Cells.................................. 3

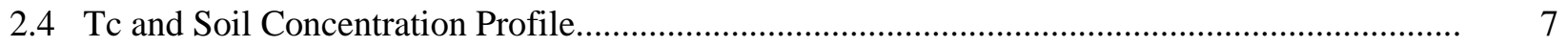

2.5 Concentration Profile for Tc Concrete Half-Cells without Tc Spike........................................ 8

2.6 Technetium Concentration Profiles for Concrete Half-Cells with Tc Spike .............................. 10

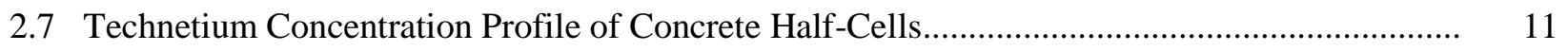

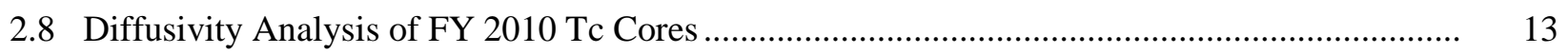

4.1 Chemical Composition of Portland Cement-Equilibrated Waters ............................................. 2

4.2 Results of Linear Combination Fit of Autunite Solubility Tests .............................................. 2

4.3 Results of Linear Combination Fit of Soddyite Solubility Tests ........................................... 5 



\subsection{Introduction}

\subsection{Background}

One of the methods being considered for safely disposing of Category 3 low-level radioactive wastes is to encase the waste in concrete. Concrete encasement would contain and isolate the waste packages from the hydrologic environment and would act as an intrusion barrier. The current plan for waste isolation consists of stacking low-level waste packages on a trench floor, surrounding the stacks with reinforced steel, and encasing these packages in concrete. These concrete-encased waste stacks are expected to vary in size with maximum dimensions of $6.4 \mathrm{~m}$ long, $2.7 \mathrm{~m}$ wide, and $4 \mathrm{~m}$ high. The waste stacks are expected to have a surrounding minimum thickness of $15 \mathrm{~cm}$ of concrete encasement. These concrete-encased waste packages are expected to withstand environmental exposure (solar radiation, temperature variations, and precipitation) until an interim soil cover or permanent closure cover is installed; they also are expected to remain largely intact thereafter. Any failure of concrete encasement may result in water intrusion and consequent mobilization of radionuclides from the waste packages.

Key contaminants within low activity and secondary wastes from treatment of the Hanford tank wastes include 129I, 75Se, 99Tc, and 238U (Wood and Khaleel et al. 1995, Mann and Puigh II et al. 2001). The geochemistry of porefluids in contact with cementitious materials is characterized by highly alkaline $\mathrm{pH}$ values. Because of their anionic nature in aqueous solutions, 129I, 75Se, 99Tc, and carbonate-complexed $238 \mathrm{U}$ may readily leach into the subsurface environment (Serne and Martin et al. 1989, Serne and Lokken et al. 1992, Serne and Conca et al. 1993, Serne and Martin et al. 1995) by mass flow and/or diffusion and move into the surrounding subsurface environment. Thus, it is critical to understand: 1) the speciation and interaction of the radionuclides within the concrete waste form; 2) the diffusion of radionuclide species when contacted with vadose zone pore water or groundwater; and 3) the long-term durability and weathering of concrete waste forms under environmental conditions relevant to the depository.

Although significant research has been conducted on the design and performance of cementitious waste forms, the current protocol conducted to assess radionuclide stability within these waste forms has been limited to the Toxicity Characteristic Leaching Procedure, Method 1311 Federal Registry and ANSI/ANS-16.1 leach test (ANSI 1986). These tests evaluate the performance under water-saturated conditions and do not evaluate the performance of cementitious waste forms within the context of waste depositories that are located in hydraulically unsaturated environments. Moreover, these tests assess only the diffusion of radionuclides from concrete waste forms and neglect evaluating the mechanisms of retention, stability of the waste form, and formation of secondary phases during weathering, which may serve as long-term secondary hosts for immobilization of radionuclides.

The results of recent investigations conducted under arid and semi-arid conditions provide valuable information suggesting structural and chemical changes to concrete waste forms which may affect contaminant containment and waste form performance (Al-Khayat and Haque et al. 2002, Garrabrants and Sanchez et al. 2002, Sanchez and Gervais et al. 2002, Garrabrants and Kosson 2003, Sanchez and Garrabrants et al. 2003, Garrabrants and Sanchez et al. 2004, Gervais and Garrabrants et al. 2004). A recent review conducted by the National Academies of Science recognized the efficacy of cementitious materials for waste isolation, but further noted the significant shortcomings in our current understanding 
and testing protocol for evaluating the performance of various formulations (Academies 2009).

Continued research is necessary to understand:

- the mechanism of contaminant release and the significance of contaminant release pathways

- how waste form performance is affected by the full range of environmental conditions within the disposal facility

- the process of waste form aging under conditions that are representative of processes occurring in response to changing environmental conditions within the disposal facility, and

- the effect of waste form aging on chemical, physical, and radiological properties and the associated impact on contaminant release.

\subsection{Purpose and Scope}

The objective of the investigation reported here is to collect data that 1) quantifies radionuclide retention within concrete waste form materials similar to those used to encapsulate waste in the LowLevel Waste Burial Grounds (LLBG); 2) measures the effect of concrete waste form properties likely to influence radionuc1ide migration; and 3) quantifies the stability of U-bearing solid phases of limited solubility in concrete. Specific subtasks, outlined below, will be used to collect the necessary data for LER analysis.

\subsection{Report Contents and Organization}

The ensuing sections of this report present the results of the concrete-soil half-cell tests, modeling of uranium (VI) solubility in concrete pore waters, single-pass flow-through tests on cementitious waste forms, and preparation of simulated tank waste concrete half-cell tests.

- Section 2.0 describes the diffusion experiments initiated during FY 2010 to determine the effects of concrete carbonation and colloidal iron on the diffusion of technetium using carbonated and uncarbonated concrete-soil half-cells prepared with and without metallic iron, half of which were carbonated using carbonate solution.

- Section 3.0 describes the set of PUF experiments initiated during FY 2009 to determine the long term stability of concrete waste forms under unsaturated sediments.

- Section 4.0 provides results from Extended Absorption X-ray Fine Structure (EXAFS) spectroscopic analyses to provide further information supporting the preliminary identifications of uranium phases to better understand the long-term stability and controls of uranium provided by concrete waste forms. This section also provides recommendations on solubility of uranium in concrete waste forms and Hanford vadose zone sediments.

- Section 5.0 discusses a comprehensive compilation of all diffusion data, analysis, and a summary that will provide a basis to predict diffusivity of I and Tc into and out of waste forms and the encasing vadose zone soils. In addition, the results of the probit analyses and quantification of diffusion coefficients are being utilized to calculate the diffusion of I, Re, and Tc through 6 inches of concrete. 


\subsection{Materials and Methods}

\subsection{Specified Concrete Composition for Encasement}

Table 2.1. Material Specifications and Composition

\begin{tabular}{lllc}
\hline \multicolumn{1}{c}{ Material } & \multicolumn{1}{c}{ Specifications } & $\begin{array}{c}\text { Normalized } \\
\text { Specified Field } \\
\text { Mix }\end{array}$ & $\begin{array}{c}\text { Specification } \\
\text { Design }\end{array}$ \\
\hline Cement & Portland Type I or Type I/II sulfate-resistant cement & $381 \mathrm{~kg} / \mathrm{m}^{3}$ & 0.27 \\
Fly Ash & Class F fly ash; nominal 15\% of cement by volume & $54 \mathrm{~kg} / \mathrm{m}^{3}$ & 0.04 \\
Coarse Aggregate & No. 676 or equivalent (3/4" nominal size) & $55 \%$ by volume & 0.04 \\
Fine Aggregate & Sand & $45 \% \mathrm{by} \mathrm{volume}$ & 0.51 \\
Water & Nominal water:cement ratio: 0.4 & $399 \mathrm{~kg} / \mathrm{m}^{3}$ & 0.10 \\
Steel Fiber & Deformed Type I, nominal length $2.5-3.8 \mathrm{~cm}\left(1-1.5^{\prime \prime}\right)$ & $59 \mathrm{~kg} / \mathrm{m}^{3}$ & 0.04 \\
Air Content & & $6.0 \pm 1.5 \%$ & \\
\hline
\end{tabular}

The concrete composition for the burial encasement was specified in Specification for Concrete Encasement for Contact-Handled Category 3 Waste (1998) ${ }^{\text {(a) }}$. This specification was used as the basis to prepare a concrete for fabrication of test specimens. The composition includes sulfate-resistant Portland Type I or Type II cement, a pozzolanic material (Class F fly ash), fine and coarse aggregates, and steel fiber. Additional specifications include a water-to-cement ratio of 0.4 and an air content $6.0 \pm 1.5 \%$. The nominal proportions and material specifications based on this initial design are listed in Table 2.1.

\subsubsection{Materials and Laboratory-Scale Mixture Design}

A laboratory-scale concrete mixture (Table 2.2) was prepared based on specifications shown in Table 2.1. Because of the required small dimensions of laboratory test specimens, the size of the coarse aggregate and the dimensions of the steel fiber specified in Table 2.1 were proportionately reduced. This was accomplished by decreasing the $2-\mathrm{cm}(\sim 0.75 \mathrm{in}$.) coarse aggregate size in the original specification to a particle size ranging from $2.83 \mathrm{~mm}$ to $2 \mathrm{~mm}$ in the laboratory mix. Aggregate passing a 7-mesh sieve and retained on a 10-mesh sieve met this particle size specification. Iron particles were used in the laboratory mix in place of the steel fibers. Based on these modifications, a concrete mix was prepared that consisted of Portland Cement (Type I and II, American Society for Testing and Materials C-150 compliant), Class F fly ash, scaled-down coarse aggregate, fine aggregate, iron particles, and a waterentraining agent (Polyheed 997). The water-entraining agent was included in the mix to facilitate the workability of the concrete. The volumes of the Polyheed 997 and the air-entraining agent, MB AE 90, were not included in the normalization calculations because of their negligible contribution to the overall mix volume. The material specification and composition for the laboratory-scale concrete mixture is given in Table 2.2. 
Table 2.2. Laboratory-Scale Material Specification and Composition

\begin{tabular}{|c|c|c|c|}
\hline Material & $\begin{array}{l}\text { Material Specifications for } \\
\text { Field Mix }\end{array}$ & $\begin{array}{c}\text { Normalized } \\
\text { Laboratory Design }\end{array}$ & $\begin{array}{c}\text { Material Specifications Used in } \\
\text { Revised Laboratory Mix } \\
\text { Comparison }\end{array}$ \\
\hline Cement & $\begin{array}{l}\text { Portland Type I or Type I/II } \\
\text { sulfate-resistant cement }\end{array}$ & 0.27 & Portland Type I \& II \\
\hline Fly Ash & $\begin{array}{l}\text { Class F fly ash; nominal } 15 \% \text { of } \\
\text { cement by volume }\end{array}$ & 0.04 & $\begin{array}{l}\text { Class F fly ash; nominal } 20 \% \text { of } \\
\text { cement by volume }\end{array}$ \\
\hline $\begin{array}{c}\text { Coarse } \\
\text { Aggregate }\end{array}$ & $\begin{array}{l}\text { No. } 676 \text { or equivalent } \\
\text { (3/4-in. nominal size) }\end{array}$ & 0.04 & $\begin{array}{l}\text { Sieve size }+7 \text { to }-10 \\
(2.83-2 \mathrm{~mm} \text { size })\end{array}$ \\
\hline Fine Aggregate & Sand & 0.51 & Sand -10 sieve size $(<2 \mathrm{~mm})$ \\
\hline Water & Nominal water:cement ratio: 0.4 & 0.10 & Water-to-cement ratio: 0.5 \\
\hline Iron Powder & Iron particles & 0.04 & -200 mesh \\
\hline Polyheed 997 & & 0.00375 & Water-entraining agent \\
\hline Air Content & $6.0 \pm 1.5 \%$ & $6.0 \pm 1.5 \%$ & -- \\
\hline
\end{tabular}

\subsection{Concrete Mix and Specimen Preparation}

In general, concrete monoliths were prepared with mix components added in this order: water, steel (if applicable), coarse aggregate, fine aggregate, fly ash, cement, Polyheed 997, and MB AE 90. The concrete was mixed on medium speed using a Hobart three-speed, bench-top mixer in a $4 \mathrm{~L}$ steel bowl. The concrete molds for casting specimens were fabricated from Schedule 40 polyvinyl chloride (PVC) piping material. Gaskets were glued to the bottom of the molds and leak tested before use. The PVC molds were filled in the vertical position. After filling, the molds were lightly tapped on the laboratory bench until a significant decrease in the release of air bubbles was observed. The forms were stored in a humidity chamber for 28 days to provide moisture while the concrete set. The concrete monoliths were subsequently removed from the molds and the respective monoliths were carbonated by soaking for 7 days in a saturated sodium-bicarbonate solution. Specific treatments for concrete monoliths (e.g., carbonation, iron content, contaminant content) used in concrete-sediment half-cell experiments are discussed below within the context of the respective half-cell preparation.

\subsection{Fractured Concrete-Sediment Half-Cells Spiked with lodine and Technetium}

Concrete monoliths were prepared in two separate batches based on the laboratory-scale specifications for the concrete (Table 2.2). One batch contained iron particles; the other batch did not contain any added iron. Within the two batches of concrete, with and without iron, half the monoliths were carbonated by submersion in a saturated sodium bicarbonate solution for 7 days. The resulting compositions consisted of four concrete specimens: 1) no iron, carbonated; 2) no iron, uncarbonated; 3 ) iron, carbonated; and 4) iron, uncarbonated. Half of the concrete specimens were spiked with Tc in order to study the diffusion of Tc from concrete into soil. 
In order to assess the effect of fractures within the concrete monolith on the diffusion of technetium, concrete monoliths were encased in shrinkwrap and struck with a hammer to prevent the formation of rubble. Each fractured core possessed a single fracture extending the length of the core, perpendicular to the concrete-sediment interface. The characteristics of the FY 2010 concrete half-cells are listed in Table 2.3.

Table 2.3. Characteristics of Concrete Specimens Used in Concrete-Soil Half-Cells

\begin{tabular}{|c|c|c|c|c|c|c|c|c|c|c|}
\hline Core ID & $\begin{array}{l}\text { Length } \\
(\mathrm{cm})\end{array}$ & $\begin{array}{c}\text { Diameter } \\
(\mathrm{cm})\end{array}$ & $r^{2}$ & $\begin{array}{c}\text { Surface } \\
\text { Area } \\
\left(\mathrm{cm}^{2}\right)\end{array}$ & $\begin{array}{c}\text { Volume } \\
\left(\mathrm{cm}^{3}\right)\end{array}$ & $\begin{array}{l}\text { Weight } \\
(\mathrm{g})\end{array}$ & $\begin{array}{l}\text { Density } \\
\left(\mathrm{g} / \mathrm{cm}^{3}\right)\end{array}$ & $\begin{array}{l}\text { Colloidal } \\
\text { Iron }(\%)\end{array}$ & Carbonated & Moisture \\
\hline \multicolumn{11}{|c|}{ FY 2010 Diffusion Tests } \\
\hline C-10-5-0-101 & 4.36 & 4.34 & 4.70 & 88.99 & 64.46 & 138.83 & 2.15 & 0 & $\mathrm{~N}$ & 4 \\
\hline C-10-5-0-102 & 4.37 & 4.34 & 4.71 & 89.25 & 64.74 & 139.22 & 2.15 & 0 & Y & 4 \\
\hline C-10-5-4-105 & 4.28 & 4.34 & 4.71 & 88.00 & 63.37 & 137.39 & 2.17 & 4 & $\mathrm{~N}$ & 4 \\
\hline C-10-5-4-106 & 4.25 & 4.34 & 4.71 & 87.52 & 62.86 & 135.92 & 2.16 & 4 & $\mathrm{Y}$ & 4 \\
\hline C-10-5-8-107 & 4.19 & 4.32 & 4.67 & 86.22 & 64.46 & 136.41 & 2.22 & 8 & $\mathrm{~N}$ & 4 \\
\hline C-10-5-8-108 & 4.14 & 4.32 & 4.67 & 85.54 & 60.73 & 134.30 & 2.21 & 8 & $\mathrm{Y}$ & 4 \\
\hline C-10-5-12-110 & 4.23 & 4.32 & 4.67 & 86.79 & 62.07 & 138.96 & 2.24 & 12 & $\mathrm{~N}$ & 4 \\
\hline C-10-5-12-111 & 4.38 & 4.34 & 4.71 & 89.33 & 64.83 & 145.49 & 2.24 & 12 & $\mathrm{Y}$ & 4 \\
\hline C-10-5-0-202 & 4.29 & 4.32 & 4.66 & 57.52 & 62.87 & 140.34 & 2.23 & 0 & $\mathrm{~N}$ & 4 \\
\hline C-10-5-0-203 & 4.51 & 4.34 & 4.71 & 91.09 & 66.73 & 149.74 & 2.24 & 0 & $\mathrm{Y}$ & 4 \\
\hline C-10-5-4-204 & 4.42 & 4.32 & 4.66 & 89.21 & 64.68 & 146.88 & 2.27 & 4 & $\mathrm{~N}$ & 4 \\
\hline C-10-5-4-205 & 4.67 & 4.32 & 4.66 & 92.64 & 68.39 & 155.53 & 2.27 & 4 & $\mathrm{Y}$ & 4 \\
\hline C-10-5-8-207 & 4.56 & 4.32 & 4.67 & 91.19 & 66.82 & 153.63 & 2.30 & 8 & $\mathrm{~N}$ & 4 \\
\hline C-10-5-8-208 & 4.53 & 4.32 & 4.67 & 90.85 & 66.46 & 152.56 & 2.30 & 8 & $\mathrm{Y}$ & 4 \\
\hline C-10-5-12-210 & 4.63 & 4.32 & 4.67 & 92.22 & 67.94 & 157.43 & 2.32 & 12 & $\mathrm{~N}$ & 4 \\
\hline C-10-5-12-211 & 4.61 & 4.32 & 4.67 & 91.90 & 67.95 & 157.06 & 2.32 & 12 & $\mathrm{Y}$ & 4 \\
\hline
\end{tabular}

\subsection{Half-Cell Preparation, Testing, and Analysis}

Diffusion tests were conducted to assess the effects of carbonation and the inclusion of colloidal iron on the rate of diffusion of Tc in unsaturated Hanford sediments at $\sim 4 \%$ moisture content by weight. The experiments were conducted using a sediment half-cell $\sim 4 \mathrm{~cm}$ in diameter and $20-\mathrm{cm}$ long in contact with a concrete monolith $\sim 4 \mathrm{~cm}$ in diameter and $\sim 4-\mathrm{cm}$ long. One concrete core of each composition was encased in a Schedule 40, 24-cm long, PVC pipe. The remaining volume of each pipe was filled with Hanford Site sediment. The concrete core specimen half-cells that were not spiked with Tc were spiked with stable Tc to the water component prior to mixing with the sediment, at the respective moisture content. Medium coarse sand obtained from the sidewall of the W-5 burial ground located on the Hanford Site in southeastern Washington State was used for the sediment half-cell. The physical, chemical, and mineralogical properties of this sediment have been previously characterized by Serne et al. (1993). The ends of each pipe were machined and fit with o-ring gaskets to confirm the test cells were sealed. The diffusion tests were allowed to set horizontally and undisturbed for 6 months, with periodic rotation of the cell by 90 degrees. 
At the conclusion of the test period, the end caps of the cells were removed and the sediment was extruded at approximately $1 \mathrm{~cm}$ intervals along the length of the half-cell (Figure 2.1). The moisture content of each section was quantified and found to be uniform throughout the length of the half-cell and consistent with the starting moisture content. The sediment samples were weighed and extracted with deionized water. One-to-one water extracts were done on sediment fractions. The concentrations of Tc was measured via ICP-MS.

Concrete half-cells were sectioned parallel to the concrete-sediment interface using a Buehler slowspeed saw fitted with a diamond blade. During the process, cutting was done without water cooling to prevent the leaching of soluble Tc. The concrete slices were then ground using an agate mortar and pestle. Two-to-one extracts (due to small sample size) were performed on concrete fractions. The concentrations of Tc were measured via ICP-MS in sediment and concrete thin slices.
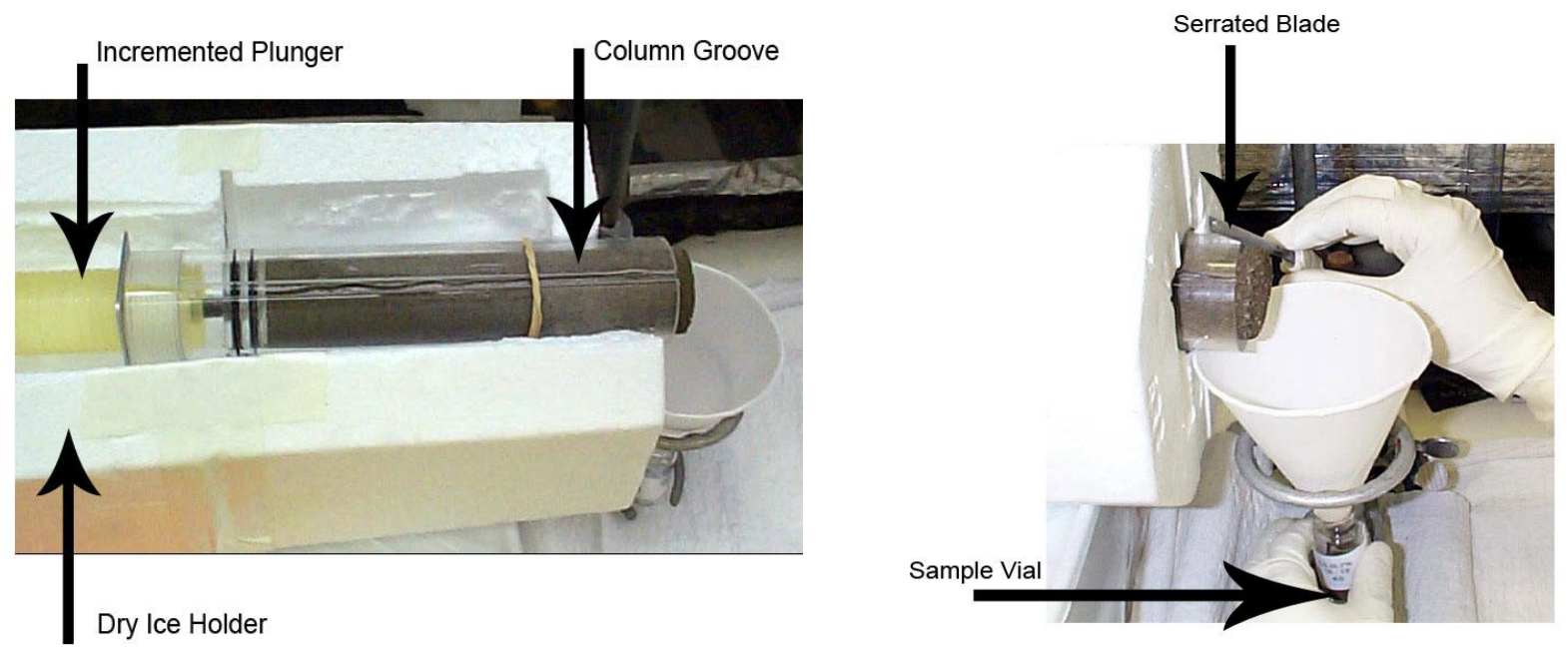

Figure 2.1. Mechanism for Sediment Sampling from a Concrete-Sediment Diffusion Half-Cell (left) and Sediment Sampling from a Diffusion Half-Cell (right)

\subsection{Effective Diffusion Coefficient Calculations}

The diffusivities in the soil were reduced using the probit analysis approach previously presented by (Mattigod and Whyatt et al. 2001). The details of the probit analysis are provided in Finney's $\underline{\text { Probit }}$ Analysis (1971). This technique allows the transformation of a sigmoid curve of concentrations, normalized with respect to the initial concentration $\left(C / C_{0}\right)$, as a function of diffusion distance produced in a half-cell diffusion experiment to a linear plot. The slope (b) of this plot is then used to calculate the diffusivity $(D)$ as $D=1 /\left(2 \mathrm{~b}^{2} t\right)$, where $t$ is the sampling time. This approach has been used previously to determine diffusivity in half-cell diffusion experiments such as those conducted by Brown et al. (1964) and Lamar (1989).

In a diffusion test where one boundary can be represented by a constant concentration, the concentration profile that develops is one-half of the normal sigmoid curve produced in the half-cell diffusion experiment. Thus, to apply the probit transformation, the concentrations are normalized by 
dividing by $2^{*} C_{i}$, where $C_{i}$ is the concentration at the constant concentration interface. This approach has been used to model diffusion from a non-depleting reservoir into asphalt (Martin and Serne et al. 1994).

The configuration of concrete-soil experiments had the soil in a half-cell arrangement with a dissimilar material (hardened concrete) containing the radionuclide spike. In the case of diffusion occurring between two dissimilar media, one of which is spiked and both of which are semi-infinite in dimension from the interface, the concentration at the interface will quickly reach and remain at a constant concentration as the diffusion proceeds. For an explanation of why this occurs, refer to Crank (1975). Because of this result, the problem is mathematically the same as the case where a boundary is held at a constant concentration and the data can be normalized by dividing by $2^{*} C_{i}$, where $C_{i}$ is the concentration at the interface. However, because the concentration $C_{i}$ at the interface of the two dissimilar materials is not known, the concentration in the soil slice nearest the interface is used to approximate this value. This approximation introduces some bias in the calculated diffusivity because the concentration profile averaged over the first soil slice is systematically lower than the concentration at the interface of the first soil slice with the spiked concrete. The extent of the error is estimated to be about $12 \%$ from one of the concentration profiles (Crane and Benny et al. 1992). We assumed the relative errors for the other tests were similar. This error magnitude is considered acceptable relative to the variance in the diffusivity values for all the tests.

For purposes of data reduction, the radionuclide diffusivity is defined by the equation:

$$
J=-D_{w} \mathrm{~d} C_{w} / \mathrm{dx}
$$

where $\quad J=$ flux of radionuclide at a given point

$D_{w}=$ the diffusivity of water-based radionuclide concentration

$C_{w}=$ the radionuclide concentration in the pore water

Using this definition, and acknowledging that in the case of a two-phase system (water and soil) there will be insignificant amounts of radionuclides within the air phase of the unsaturated sediment, a mass balance can be performed over a small volume leading to the equation

$$
\mathrm{d} C_{w} / \mathrm{dt}=D_{w} / \theta^{*}\left(\mathrm{~d}^{2} C_{w} / \mathrm{dx}^{2}\right)
$$

where $\theta=$ the volume pore water per total pore volume

However, the slope on the probit plot provides the diffusivity that solves the equation for diffusion in a homogeneous single phase medium:

$$
\mathrm{d} C / \mathrm{dt}=D^{*}\left(\mathrm{~d}^{2} C / \mathrm{dx}^{2}\right)
$$

The diffusion coefficient, $D_{w}$, was calculated from $D$ obtained from the probit plot based on concentrations in the pore water that must then be multiplied by $\theta$. From concrete-soil experiments, the diffusivity coefficients in concrete were calculated using soil diffusivity coefficients derived from probit plots. 


\subsection{Results and Discussion}

\subsubsection{Concentration Profile}

The diffusion profiles of soil half-cells spiked with Tc are shown in Figure 2.2. The diffusion profile of the concrete half-cells is shown in Figure 2.3. Except very near the interfaces, no distinctive concentration gradients were observed in any of the soil half-cells. Therefore, on average, the relatively constant concentrations throughout the soil half-cells reflected the spike concentrations of Tc.
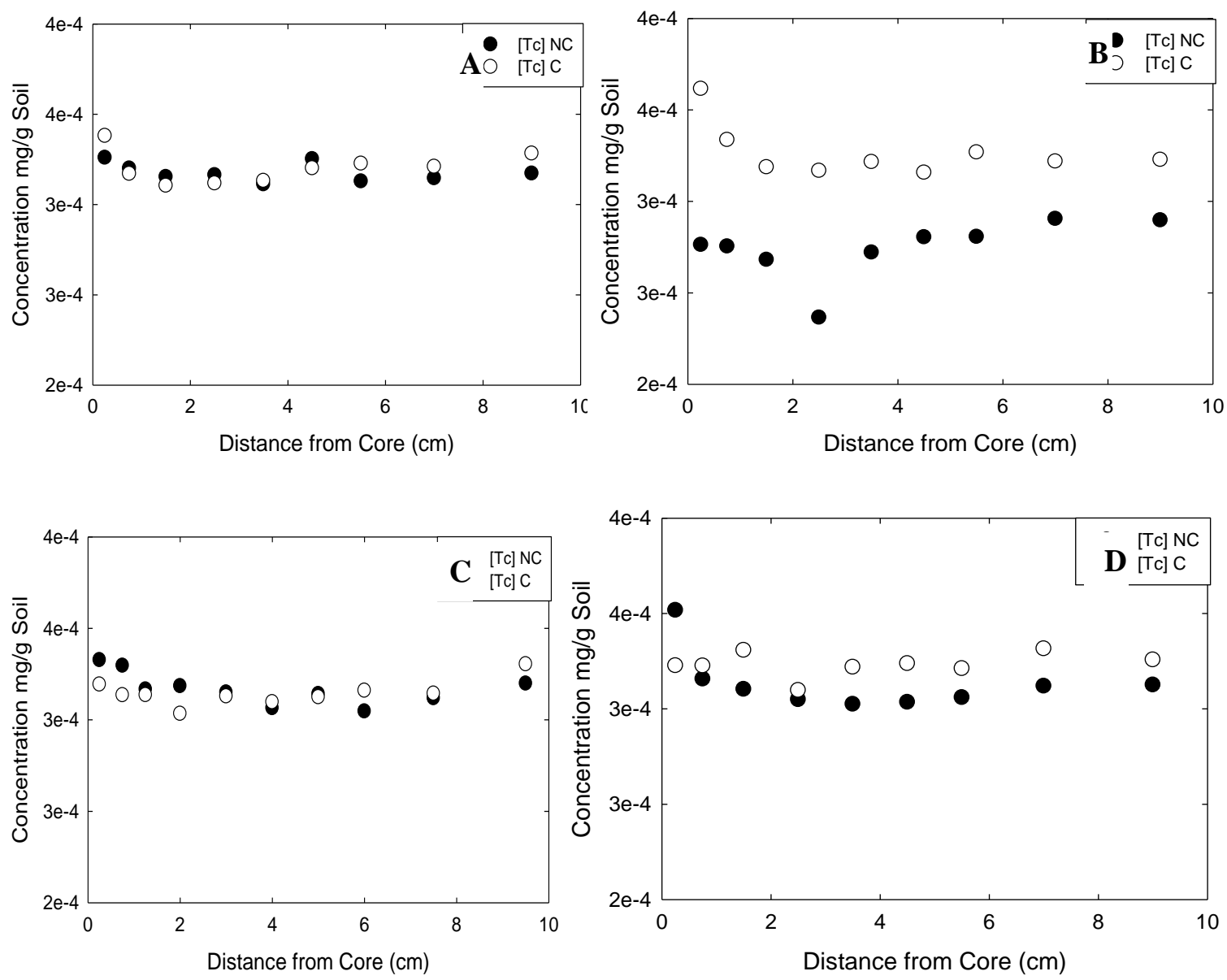

Figure 2.2. Tc Soil Concentration Profiles for Carbonated and Non-Carbonated Cores

A) $4 \%$ Soil Moisture, 0\% Fe, B) 4\% Soil Moisture, 4\% Fe, C) $4 \%$ Soil Moisture, $8 \%$ Fe, D) 4\% Soil Moisture, $12 \%$ Fe 
Table 2.4. Tc and Soil Concentration Profile

\begin{tabular}{|c|c|c|c|c|c|c|c|}
\hline $\begin{array}{c}\text { Distance } \\
\text { From Core, } \\
\mathrm{cm}\end{array}$ & $\mathrm{Tc}, \mathrm{mg} / \mathrm{g}$ & $\begin{array}{c}\text { Distance } \\
\text { From Core, } \\
\mathrm{cm}\end{array}$ & $\mathrm{Tc}, \mathrm{mg} / \mathrm{g}$ & $\begin{array}{l}\text { Distance } \\
\text { From } \\
\text { Core, } \mathrm{cm}\end{array}$ & $\mathrm{Tc}, \mathrm{mg} / \mathrm{g}$ & $\begin{array}{c}\text { Distance } \\
\text { From Core, } \\
\mathrm{cm}\end{array}$ & $\mathrm{Tc}, \mathrm{mg} / \mathrm{g}$ \\
\hline \multicolumn{2}{|c|}{$4 \%$ Soil--NC 0\% Iron } & \multicolumn{2}{|c|}{$4 \%$ Soil--NC 4\% Iron } & \multicolumn{2}{|c|}{ 4\% Soil--C 0\% Iron } & \multicolumn{2}{|c|}{$4 \%$ Soil--C-4\% Iron } \\
\hline 9 & $3.17 \mathrm{E}-04$ & 9 & $2.90 \mathrm{E}-04$ & 9 & $3.28 \mathrm{E}-04$ & 9 & $3.23 \mathrm{E}-04$ \\
\hline 7 & $3.15 \mathrm{E}-04$ & 7 & $2.90 \mathrm{E}-04$ & 7 & $3.21 \mathrm{E}-04$ & 7 & $3.22 \mathrm{E}-04$ \\
\hline 5.5 & $3.13 \mathrm{E}-04$ & 5.5 & $2.81 \mathrm{E}-04$ & 5.5 & 3.23E-04 & 5.5 & $3.27 \mathrm{E}-04$ \\
\hline 4.5 & $3.25 \mathrm{E}-04$ & 4.5 & $2.80 \mathrm{E}-04$ & 4.5 & $3.20 \mathrm{E}-04$ & 4.5 & $3.16 \mathrm{E}-04$ \\
\hline 3.5 & $3.11 \mathrm{E}-04$ & 3.5 & $2.72 \mathrm{E}-04$ & 3.5 & 3.13E-04 & 3.5 & $3.22 \mathrm{E}-04$ \\
\hline 2.5 & $3.16 \mathrm{E}-04$ & 2.5 & $2.36 \mathrm{E}-04$ & 2.5 & $3.12 \mathrm{E}-04$ & 2.5 & 3.17E-04 \\
\hline 1.5 & $3.15 \mathrm{E}-04$ & 1.5 & $2.68 \mathrm{E}-04$ & 1.5 & $3.10 \mathrm{E}-04$ & 1.5 & $3.19 \mathrm{E}-04$ \\
\hline 0.75 & $3.20 \mathrm{E}-04$ & 0.75 & $2.75 \mathrm{E}-04$ & 0.75 & $3.17 \mathrm{E}-04$ & 0.75 & $3.34 \mathrm{E}-04$ \\
\hline 0.25 & $3.26 \mathrm{E}-04$ & 0.25 & $2.76 \mathrm{E}-04$ & 0.25 & 3.38E-04 & 0.25 & $3.62 \mathrm{E}-04$ \\
\hline \multicolumn{2}{|c|}{$4 \%$ Soil--NC 8\% Iron } & \multicolumn{2}{|c|}{$4 \%$ Soil--NC $12 \%$ Iron } & \multicolumn{2}{|c|}{$4 \%$ Soil--C $8 \%$ Iron } & \multicolumn{2}{|c|}{$4 \%$ Soil--C-12\% Iron } \\
\hline 9.5 & $3.20 \mathrm{E}-04$ & 9 & $3.13 \mathrm{E}-04$ & 9.5 & $3.30 \mathrm{E}-04$ & 9 & $3.26 \mathrm{E}-04$ \\
\hline 7.5 & $3.12 \mathrm{E}-04$ & 7 & $3.12 \mathrm{E}-04$ & 7.5 & $3.14 \mathrm{E}-04$ & 7 & $3.31 \mathrm{E}-04$ \\
\hline 6 & $3.05 \mathrm{E}-04$ & 5.5 & $3.06 \mathrm{E}-04$ & 6 & $3.16 \mathrm{E}-04$ & 5.5 & $3.21 \mathrm{E}-04$ \\
\hline 5 & $3.14 \mathrm{E}-04$ & 4.5 & $3.03 \mathrm{E}-04$ & 5 & $3.12 \mathrm{E}-04$ & 4.5 & $3.24 \mathrm{E}-04$ \\
\hline 4 & $3.06 \mathrm{E}-04$ & 3.5 & $3.02 \mathrm{E}-04$ & 4 & $3.10 \mathrm{E}-04$ & 3.5 & $3.22 \mathrm{E}-04$ \\
\hline 3 & $3.15 \mathrm{E}-04$ & 2.5 & $3.05 \mathrm{E}-04$ & 3 & 3.13E-04 & 2.5 & $3.10 \mathrm{E}-04$ \\
\hline 2 & $3.18 \mathrm{E}-04$ & 1.5 & $3.10 \mathrm{E}-04$ & 2 & $3.03 \mathrm{E}-04$ & 1.5 & $3.31 \mathrm{E}-04$ \\
\hline 1.25 & $3.17 \mathrm{E}-04$ & 0.75 & $3.16 \mathrm{E}-04$ & 1.25 & $3.14 \mathrm{E}-04$ & 0.75 & $3.23 \mathrm{E}-04$ \\
\hline 0.75 & $3.30 \mathrm{E}-04$ & 0.25 & $3.52 \mathrm{E}-04$ & 0.75 & $3.14 \mathrm{E}-04$ & 0.25 & $3.23 \mathrm{E}-04$ \\
\hline 0.25 & $3.33 \mathrm{E}-04$ & & & 0.25 & $3.19 \mathrm{E}-04$ & & \\
\hline
\end{tabular}

In contrast, well-developed Tc concentration gradients from the interface were observed in concrete half-cells. Therefore, these concentration gradients were linearized by probit analyses to allow calculation of diffusion coefficients. In concrete half-cells in contact with spiked soil-cells at $4 \%$ moisture content, the carbonation of concrete treatment seemed to significantly reduce the diffusivity of Tc (Figure 2.3). Tc diffusivity in both the uncarbonated and carbonated half-cells seemed to be noticeably attenuated by the presence of Fe particles.
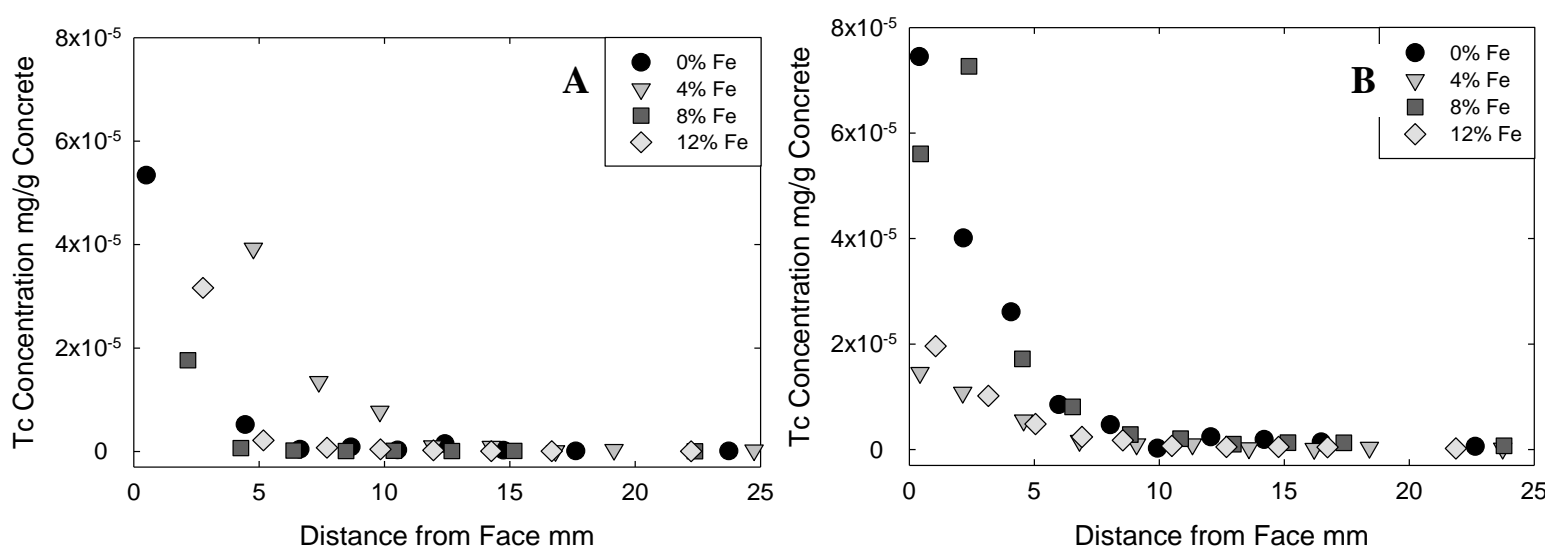

Figure 2.3. Concrete Half-Cell Concentration Profiles as a Function of Iron Content

A) Tc Concentration for Uncarbonated Concrete at 4\% Soil Moisture,

B) Tc Concentration for Carbonated Concrete at 4\% Soil Moisture 
Table 2.5. Concentration Profile for Tc Concrete Half-Cells without Tc Spike

\begin{tabular}{|c|c|c|c|c|c|c|c|}
\hline $\begin{array}{l}\text { Center of } \\
\text { Slice to } \\
\text { Face, mm }\end{array}$ & $\mathrm{Tc}, \mathrm{mg} / \mathrm{g}$ & $\begin{array}{c}\text { Center of } \\
\text { Slice to Face, } \\
\mathrm{mm}\end{array}$ & $\mathrm{Tc}, \mathrm{mg} / \mathrm{g}$ & $\begin{array}{l}\text { Center of } \\
\text { Slice to } \\
\text { Face, } \mathrm{mm}\end{array}$ & $\mathrm{Tc}, \mathrm{mg} / \mathrm{g}$ & $\begin{array}{c}\text { Center of } \\
\text { Slice to Face, } \\
\mathrm{mm}\end{array}$ & $\mathrm{Tc}, \mathrm{mg} / \mathrm{g}$ \\
\hline \multicolumn{2}{|c|}{$4 \%$ Soil--NC 0\% Iron } & \multicolumn{2}{|c|}{ 4\% Soil--NC 4\% Iron } & \multicolumn{2}{|c|}{$4 \%$ Soil--C 0\% Iron } & \multicolumn{2}{|c|}{$4 \%$ Soil--C-4\% Iron } \\
\hline 0.50 & $5.34 \mathrm{E}-05$ & 0.50 & $3.06 \mathrm{E}-04$ & 0.40 & $7.45 \mathrm{E}-05$ & 0.43 & $1.46 \mathrm{E}-05$ \\
\hline 2.29 & $1.11 \mathrm{E}-04$ & 2.36 & $4.26 \mathrm{E}-04$ & 2.16 & 4.01E-05 & 2.14 & $1.08 \mathrm{E}-05$ \\
\hline 4.45 & $5.18 \mathrm{E}-06$ & 4.77 & 3.93E-05 & 4.07 & 2.61E-05 & 4.57 & 5.55E-06 \\
\hline 6.63 & $4.30 \mathrm{E}-07$ & 7.38 & $1.35 \mathrm{E}-05$ & 5.98 & 8.52E-06 & 6.81 & $1.69 \mathrm{E}-06$ \\
\hline 8.67 & $8.73 \mathrm{E}-07$ & 9.82 & $7.75 \mathrm{E}-06$ & 8.04 & $4.69 \mathrm{E}-06$ & 9.09 & $1.03 \mathrm{E}-06$ \\
\hline 10.53 & $2.88 \mathrm{E}-07$ & 11.93 & $1.08 \mathrm{E}-06$ & 9.93 & $2.45 \mathrm{E}-07$ & 11.33 & $1.02 \mathrm{E}-06$ \\
\hline 12.41 & $1.52 \mathrm{E}-06$ & 14.26 & $9.62 \mathrm{E}-07$ & 12.06 & $2.38 \mathrm{E}-06$ & 13.59 & 2.91E-07 \\
\hline 14.75 & $2.38 \mathrm{E}-07$ & 16.82 & $1.12 \mathrm{E}-07$ & 14.20 & $1.89 \mathrm{E}-06$ & 16.20 & $1.73 \mathrm{E}-07$ \\
\hline 17.63 & $9.68 \mathrm{E}-08$ & 19.16 & 3.66E-07 & 16.48 & $1.41 \mathrm{E}-06$ & 18.41 & $3.69 \mathrm{E}-07$ \\
\hline 23.74 & $9.80 \mathrm{E}-08$ & 24.74 & $2.64 \mathrm{E}-07$ & 22.64 & $5.96 \mathrm{E}-07$ & 23.74 & $2.16 \mathrm{E}-07$ \\
\hline \multicolumn{2}{|c|}{$4 \%$ Soil--NC 8\% Iron } & \multicolumn{2}{|c|}{$4 \%$ Soil--NC $12 \%$ Iron } & \multicolumn{2}{|c|}{$4 \%$ Soil--C 8\% Iron } & \multicolumn{2}{|c|}{$4 \%$ Soil--C-12\% Iron } \\
\hline 0.45 & $8.14 \mathrm{E}-05$ & 0.75 & $1.48 \mathrm{E}-04$ & 0.45 & $5.6052 \mathrm{E}-05$ & 1.05 & $1.96046 \mathrm{E}-05$ \\
\hline 2.16 & $1.76 \mathrm{E}-05$ & 2.76 & $3.16 \mathrm{E}-05$ & 2.39 & 7.27E-05 & 3.16 & $1.02 \mathrm{E}-05$ \\
\hline 4.27 & $6.75 \mathrm{E}-07$ & 5.17 & $2.15 \mathrm{E}-06$ & 4.52 & $1.72 \mathrm{E}-05$ & 5.05 & 4.83E-06 \\
\hline 6.38 & $2.00 \mathrm{E}-07$ & 7.71 & 7.32E-07 & 6.53 & 8.09E-06 & 6.91 & 2.39E-06 \\
\hline 8.47 & $1.04 \mathrm{E}-07$ & 9.84 & $4.20 \mathrm{E}-07$ & 8.84 & $2.85 \mathrm{E}-06$ & 8.54 & $1.75 \mathrm{E}-06$ \\
\hline 10.38 & $1.37 \mathrm{E}-07$ & 11.95 & $2.42 \mathrm{E}-07$ & 10.85 & $2.06 \mathrm{E}-06$ & 10.50 & $6.78 \mathrm{E}-07$ \\
\hline 12.69 & $8.88 \mathrm{E}-08$ & 14.26 & $7.87 \mathrm{E}-08$ & 12.96 & $1.01 \mathrm{E}-06$ & 12.69 & $4.97 \mathrm{E}-07$ \\
\hline 15.17 & $1.20 \mathrm{E}-07$ & 16.67 & 7.16E-08 & 15.15 & $1.29 \mathrm{E}-06$ & 14.77 & $5.05 \mathrm{E}-07$ \\
\hline \multirow[t]{2}{*}{22.38} & $5.80 \mathrm{E}-08$ & 22.23 & $4.90 \mathrm{E}-08$ & 17.38 & $1.29 \mathrm{E}-06$ & 16.73 & $4.43 \mathrm{E}-07$ \\
\hline & & & & 23.79 & 7.03E-07 & 21.87 & $2.23 \mathrm{E}-07$ \\
\hline
\end{tabular}

The soil half-cell diffusion profiles of concrete cores spiked with Tc are shown in Figure 2.4 and the concrete half-cells are shown in Figure 2.5. Well developed Tc concentration gradients from interface were observed in soil half-cells. Therefore, these concentration gradients were linearized by probit analyses to allow calculation of diffusion coefficients. In soil half-cells in contact with spiked concrete half-cells, the carbonation of concrete seemed to significantly increase the diffusivity of Tc (Figure 2.4). Tc diffusivity in both the uncarbonated and carbonated half-cells seemed to be unaffected by the presence of Fe.

The diffusion profile of Tc in the concrete half-cells is shown in Figure 2.1. One distinctive feature of these profiles is the apparent bidirectional nature of ion diffusion in the concrete cores. The reason for such an anomaly was apparent at the end of the experiment when the half-cells were dismantled for sampling. During vertical storage of these half-cells, some of the soils from the soil half-cells at the top had worked down the gap between the concrete half-cells and the surrounding plastic tube. Therefore, the soils contacting both top and bottom of the concrete half- cells inadvertently seemed to have set up bidirectional diffusion in Tc spiked half-cells.

Except very near the interfaces, no distinctive concentration gradients were observed in any of the soil half-cells. Therefore, on average, the relatively constant concentrations throughout the soil half-cells reflected the spike concentrations of I and Tc, respectively. 

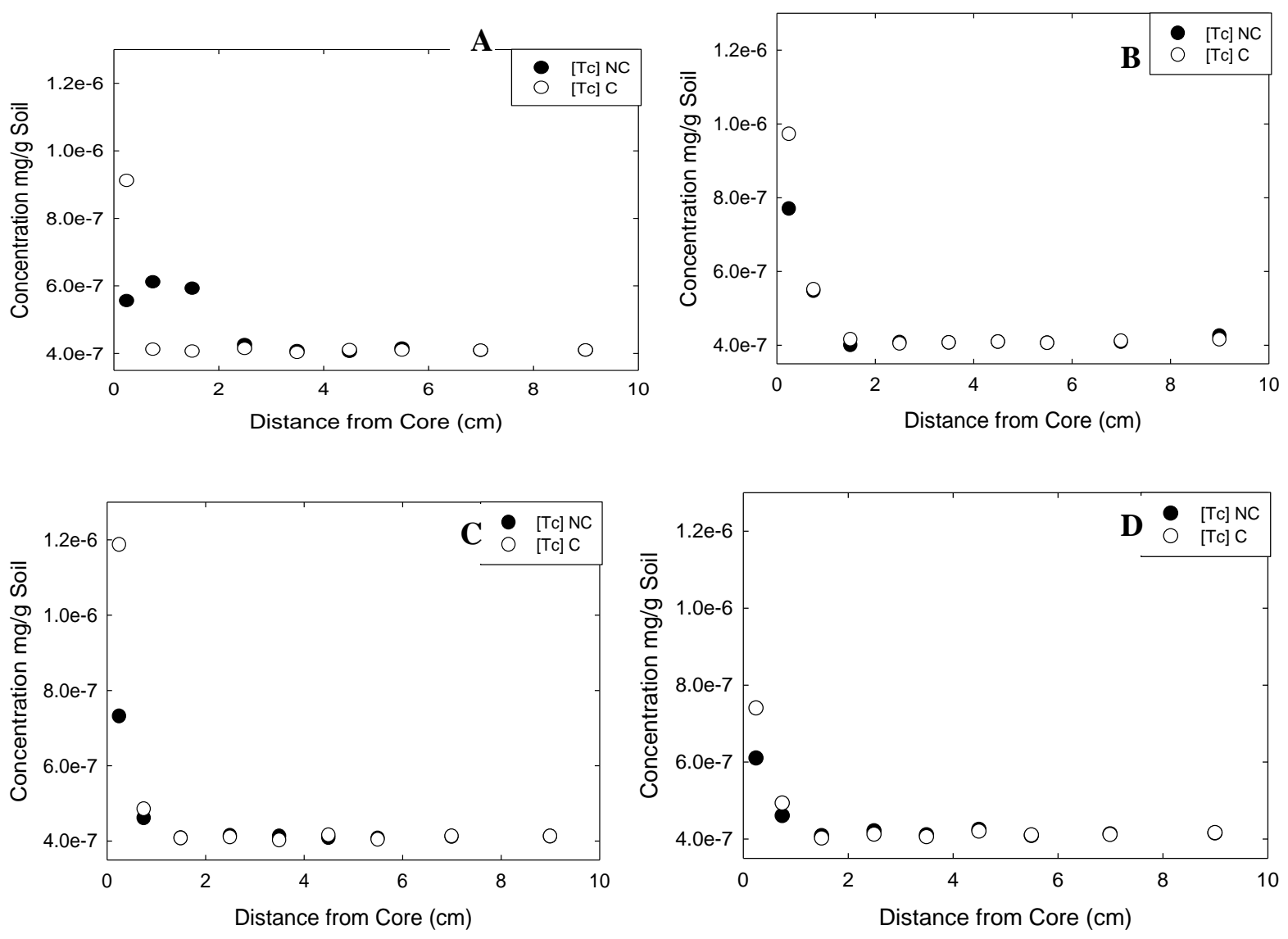

Figure 2.4. Tc Soil Concentration Profiles for Carbonated and Non-Carbonated Cores

A) $4 \%$ Soil Moisture, $0 \% \mathrm{Fe}, \mathrm{B}$ ) $4 \%$ Soil Moisture, $4 \% \mathrm{Fe}$,

C) $4 \%$ Soil Moisture, $8 \%$ Fe, D) $4 \%$ Soil Moisture, $12 \% \mathrm{Fe}$ 
Table 2.6. Technetium Concentration Profiles for Concrete Half-Cells with Tc Spike

\begin{tabular}{|c|c|c|c|c|c|c|c|}
\hline $\begin{array}{c}\text { Distance } \\
\text { From Core, } \\
\mathrm{cm}\end{array}$ & $\mathrm{Tc}, \mathrm{mg} / \mathrm{g}$ & $\begin{array}{c}\text { Distance } \\
\text { From Core, } \\
\mathrm{cm}\end{array}$ & $\mathrm{Tc}, \mathrm{mg} / \mathrm{g}$ & $\begin{array}{c}\text { Distance } \\
\text { From Core, } \\
\mathrm{cm}\end{array}$ & $\mathrm{Tc}, \mathrm{mg} / \mathrm{g}$ & $\begin{array}{c}\text { Distance } \\
\text { From Core, } \\
\mathrm{cm}\end{array}$ & $\mathrm{Tc}, \mathrm{mg} / \mathrm{g}$ \\
\hline \multicolumn{2}{|c|}{ 4\% Soil--NC 0\% Iron } & \multicolumn{2}{|c|}{ 4\% Soil--NC 4\% Iron } & \multicolumn{2}{|c|}{$4 \%$ Soil--C 0\% Iron } & \multicolumn{2}{|c|}{ 4\% Soil--C-4\% Iron } \\
\hline 9 & $4.09 \mathrm{E}-07$ & 9 & $4.25 \mathrm{E}-07$ & 9 & $4.09 \mathrm{E}-07$ & 9 & $4.15 \mathrm{E}-07$ \\
\hline 7 & $4.08 \mathrm{E}-07$ & 7 & $4.08 \mathrm{E}-07$ & 7 & $4.08 \mathrm{E}-07$ & 7 & 4.11E-07 \\
\hline 5.5 & 4.15E-07 & 5.5 & 4.06E-07 & 5.5 & 4.09E-07 & 5.5 & 4.06E-07 \\
\hline 4.5 & 4.05E-07 & 4.5 & 4.09E-07 & 4.5 & 4.10E-07 & 4.5 & $4.09 \mathrm{E}-07$ \\
\hline 3.5 & 4.07E-07 & 3.5 & 4.07E-07 & 3.5 & $4.02 \mathrm{E}-07$ & 3.5 & 4.07E-07 \\
\hline 2.5 & 4.25E-07 & 2.5 & $4.08 \mathrm{E}-07$ & 2.5 & 4.14E-07 & 2.5 & 4.04E-07 \\
\hline 1.5 & 5.92E-07 & 1.5 & $4.00 \mathrm{E}-07$ & 1.5 & 4.06E-07 & 1.5 & 4.15E-07 \\
\hline 0.75 & $6.11 \mathrm{E}-07$ & 0.75 & $5.47 \mathrm{E}-07$ & 0.75 & $4.12 \mathrm{E}-07$ & 0.75 & $5.51 \mathrm{E}-07$ \\
\hline 0.25 & $5.55 \mathrm{E}-07$ & 0.25 & 7.69E-07 & 0.25 & $9.11 \mathrm{E}-07$ & 0.25 & $9.72 \mathrm{E}-07$ \\
\hline \multicolumn{2}{|c|}{ 4\% Soil--NC $8 \%$ Iron } & \multicolumn{2}{|c|}{$4 \%$ Soil--NC $12 \%$ Iron } & \multicolumn{2}{|c|}{$4 \%$ Soil--C 8\% Iron } & \multicolumn{2}{|c|}{$4 \%$ Soil--C-12\% Iron } \\
\hline 9 & $4.12 \mathrm{E}-07$ & 9 & $4.15 \mathrm{E}-07$ & 9 & $4.12 \mathrm{E}-07$ & 9 & $4.16 \mathrm{E}-07$ \\
\hline 7 & 4.11E-07 & 7 & 4.12E-07 & 7 & 4.13E-07 & 7 & 4.11E-07 \\
\hline 5.5 & 4.07E-07 & 5.5 & $4.08 \mathrm{E}-07$ & 5.5 & 4.04E-07 & 5.5 & 4.10E-07 \\
\hline 4.5 & 4.08E-07 & 4.5 & 4.24E-07 & 4.5 & 4.15E-07 & 4.5 & 4.19E-07 \\
\hline 3.5 & 4.12E-07 & 3.5 & 4.10E-07 & 3.5 & 4.02E-07 & 3.5 & 4.05E-07 \\
\hline 2.5 & 4.14E-07 & 2.5 & 4.20E-07 & 2.5 & 4.10E-07 & 2.5 & 4.12E-07 \\
\hline 1.5 & $4.08 \mathrm{E}-07$ & 1.5 & $4.08 \mathrm{E}-07$ & 1.5 & 4.07E-07 & 1.5 & 4.02E-07 \\
\hline 0.75 & 4.61E-07 & 0.75 & 4.60E-07 & 0.75 & 4.84E-07 & 0.75 & 4.92E-07 \\
\hline 0.25 & 7.31E-07 & 0.25 & $6.09 \mathrm{E}-07$ & 0.25 & $1.19 \mathrm{E}-06$ & 0.25 & 7.39E-07 \\
\hline
\end{tabular}
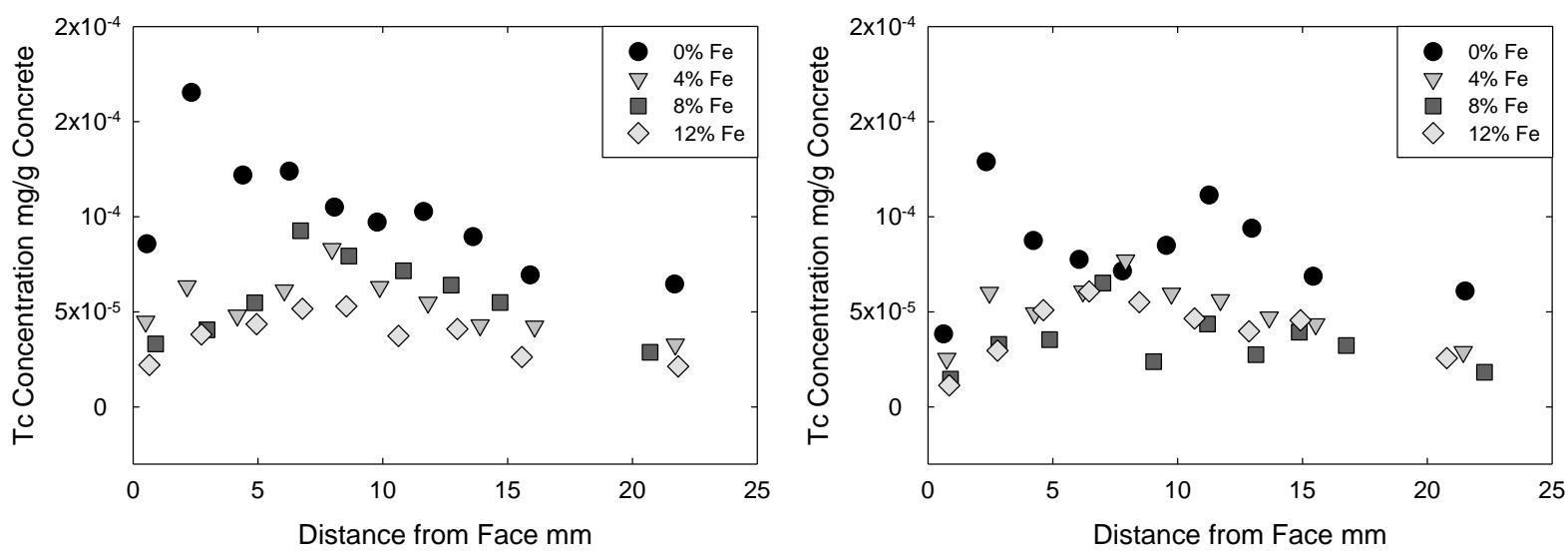

Figure 2.5. Concrete Half-Cell Concentration Profiles as a Function of Iron Content

A) Tc Concentration for Uncarbonated Concrete at 4\% Soil Moisture,

B) $\mathrm{Tc}$ Concentration for Carbonated Concrete at $4 \%$ Soil Moisture 
Table 2.7. Technetium Concentration Profile of Concrete Half-Cells

\begin{tabular}{|c|c|c|c|c|c|c|c|}
\hline $\begin{array}{c}\text { Center of } \\
\text { Slice to Face, } \\
\mathrm{mm}\end{array}$ & $\mathrm{Tc}, \mathrm{mg} / \mathrm{g}$ & $\begin{array}{c}\text { Center of } \\
\text { Slice to Face, } \\
\text { mm }\end{array}$ & $\mathrm{Tc}, \mathrm{mg} / \mathrm{g}$ & $\begin{array}{c}\text { Center of } \\
\text { Slice to } \\
\text { Face, } \mathrm{mm}\end{array}$ & $\mathrm{Tc}, \mathrm{mg} / \mathrm{g}$ & $\begin{array}{c}\text { Center of } \\
\text { Slice to } \\
\text { Face, } \mathrm{mm}\end{array}$ & $\mathrm{Tc}, \mathrm{mg} / \mathrm{g}$ \\
\hline \multicolumn{2}{|c|}{$4 \%$ Soil--NC 0\% Iron } & \multicolumn{2}{|c|}{$4 \%$ Soil--NC 4\% Iron } & \multicolumn{2}{|c|}{$4 \%$ Soil--C 0\% Iron } & \multicolumn{2}{|c|}{$4 \%$ Soil--C-4\% Iron } \\
\hline 0.55 & $8.57 \mathrm{E}-05$ & 0.50 & $4.50 \mathrm{E}-05$ & 0.63 & $3.84 \mathrm{E}-05$ & 0.75 & $2.54 \mathrm{E}-05$ \\
\hline 2.34 & $1.65 \mathrm{E}-04$ & 2.16 & $6.35 \mathrm{E}-05$ & 2.34 & $1.29 \mathrm{E}-04$ & 2.46 & $6.01 \mathrm{E}-05$ \\
\hline 4.40 & $1.22 \mathrm{E}-04$ & 4.17 & 4.82E-05 & 4.22 & $8.75 \mathrm{E}-05$ & 4.27 & 4.93E-05 \\
\hline 6.26 & $1.24 \mathrm{E}-04$ & 6.06 & $6.14 \mathrm{E}-05$ & 6.06 & $7.75 \mathrm{E}-05$ & 6.21 & $6.09 \mathrm{E}-05$ \\
\hline 8.07 & $1.05 \mathrm{E}-04$ & 7.97 & 8.31E-05 & 7.79 & 7.15E-05 & 7.92 & 7.72E-05 \\
\hline 9.78 & $9.72 \mathrm{E}-05$ & 9.88 & $6.31 \mathrm{E}-05$ & 9.55 & 8.49E-05 & 9.75 & $5.96 \mathrm{E}-05$ \\
\hline 11.64 & $1.03 \mathrm{E}-04$ & 11.81 & $5.50 \mathrm{E}-05$ & 11.26 & $1.11 \mathrm{E}-04$ & 11.71 & $5.63 \mathrm{E}-05$ \\
\hline 13.62 & $8.95 \mathrm{E}-05$ & 13.90 & 4.30E-05 & 12.97 & $9.39 \mathrm{E}-05$ & 13.67 & 4.72E-05 \\
\hline 15.91 & $6.94 \mathrm{E}-05$ & 16.08 & 4.24E-05 & 15.43 & $6.87 \mathrm{E}-05$ & 15.53 & $4.35 \mathrm{E}-05$ \\
\hline 21.69 & $6.46 \mathrm{E}-05$ & 21.72 & 3.29E-05 & 21.52 & $6.09 \mathrm{E}-05$ & 21.44 & $2.90 \mathrm{E}-05$ \\
\hline \multicolumn{2}{|c|}{$4 \%$ Soil--NC 8\% Iron } & \multicolumn{2}{|c|}{$4 \%$ Soil--NC $12 \%$ Iron } & \multicolumn{2}{|c|}{$4 \%$ Soil--C $8 \%$ Iron } & \multicolumn{2}{|c|}{$4 \%$ Soil--C-12\% Iron } \\
\hline 0.90 & $3.32 \mathrm{E}-05$ & 0.65 & $2.21 \mathrm{E}-05$ & 0.90 & $1.46 \mathrm{E}-05$ & 0.85 & $1.13 \mathrm{E}-05$ \\
\hline 2.96 & $4.06 \mathrm{E}-05$ & 2.74 & 3.82E-05 & 2.84 & $3.29 \mathrm{E}-05$ & 2.79 & $2.96 \mathrm{E}-05$ \\
\hline 4.87 & $5.48 \mathrm{E}-05$ & 4.95 & 4.35E-05 & 4.87 & 3.54E-05 & 4.62 & $5.09 \mathrm{E}-05$ \\
\hline 6.71 & $9.26 \mathrm{E}-05$ & 6.78 & $5.16 \mathrm{E}-05$ & 7.01 & $6.52 \mathrm{E}-05$ & 6.46 & $6.08 \mathrm{E}-05$ \\
\hline 8.64 & 7.94E-05 & 8.54 & $5.30 \mathrm{E}-05$ & 9.04 & 2.39E-05 & 8.47 & $5.52 \mathrm{E}-05$ \\
\hline 10.83 & $7.16 \mathrm{E}-05$ & 10.63 & 3.74E-05 & 11.20 & 4.37E-05 & 10.68 & $4.66 \mathrm{E}-05$ \\
\hline 12.74 & $6.41 \mathrm{E}-05$ & 12.99 & 4.10E-05 & 13.14 & $2.76 \mathrm{E}-05$ & 12.86 & $3.98 \mathrm{E}-05$ \\
\hline 14.70 & $5.49 \mathrm{E}-05$ & 15.57 & 2.63E-05 & 14.87 & 3.94E-05 & 14.92 & $4.56 \mathrm{E}-05$ \\
\hline \multirow[t]{2}{*}{20.71} & $2.88 \mathrm{E}-05$ & 21.83 & 2.13E-05 & 16.76 & 3.24E-05 & 20.78 & $2.57 \mathrm{E}-05$ \\
\hline & & & & 22.29 & $1.82 \mathrm{E}-05$ & & \\
\hline
\end{tabular}

\subsection{Probit Analysis Results and Discussion}

A set of diffusion experiments were initiated during FY2010 using concrete-soil half-cells containing Tc (Table 2.3). These experiments were designed to examine the effect of carbonation and $\mathrm{Fe}$ additions on Tc diffusion into concrete at a fixed soil moisture of $4 \%$. After about six months, the concrete half cells were sectioned and the Tc concentrations were measured. The resulting probit plots are shown in Figure 2.6 and Figure 2.7, and the calculated diffusion coefficients are listed in Table 2.8.

The data indicated that carbonation in all cases increased the Tc diffusion coefficient. Significant increases in Tc diffusivities were noted when cores with higher concentrations of Fe (8\% and 12\%) were carbonated. These data indicate that carbonation of Fe containing concrete cores may enhance microcracking of concrete resulting in an increase in Tc diffusivity. Similar phenomena have been noted in previous studies in which Fe containing carbonated concrete cores was in contact with Tc-spiked soil cores with $4 \%$ moisture content. Also, the beneficial effect of Fe on reducing Tc diffusivity in noncarbonated specimens is not observable until the Fe content is at least $8 \%$ by mass. 


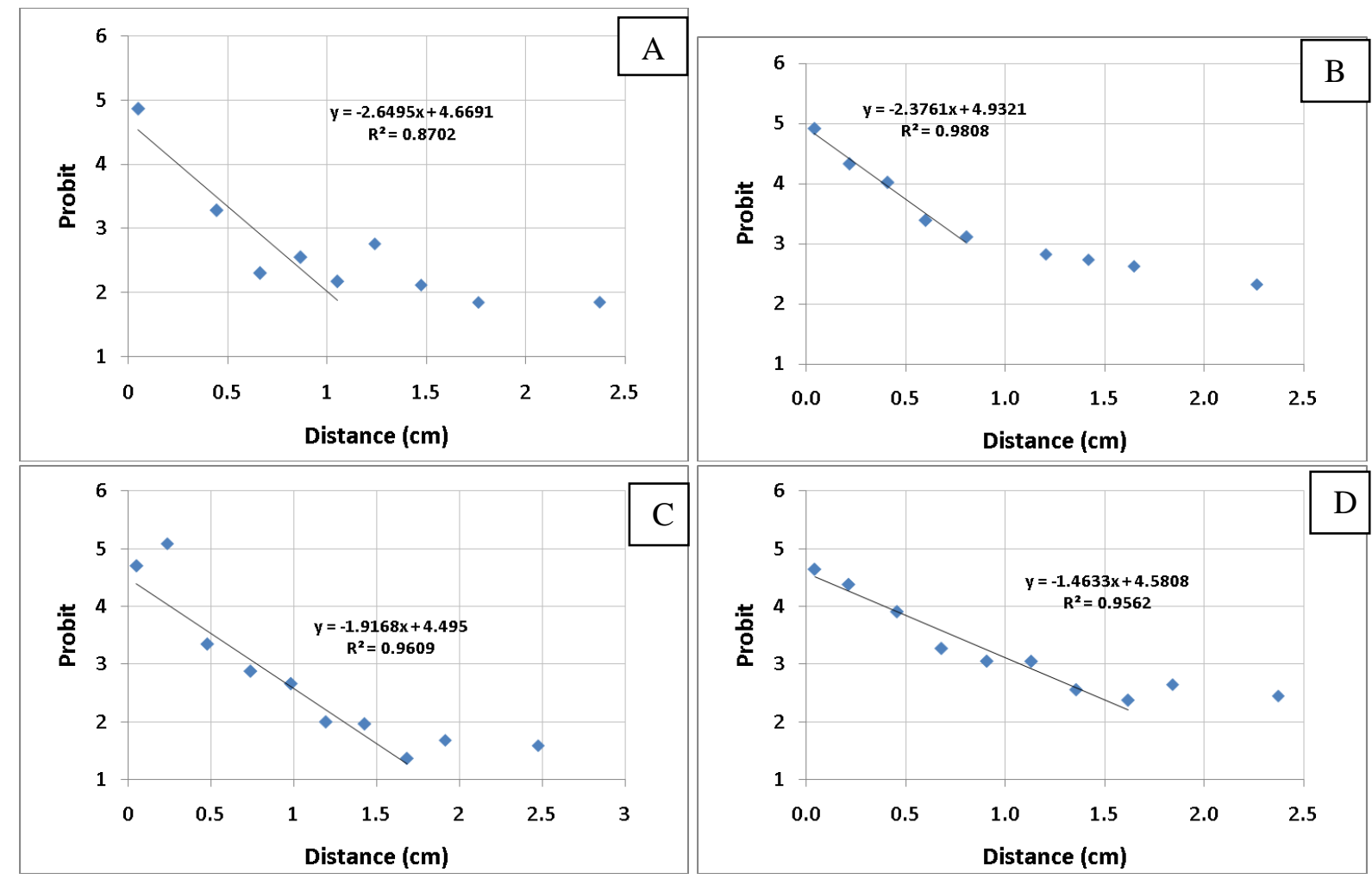

Figure 2.6. Probit Analysis of FY 2010 Tc Cores A) Tc-C-10-5-0-101, B) Tc-C-10-5-0-102, C) Tc-C-105-4-105, D) Tc-C-10-5-4-106

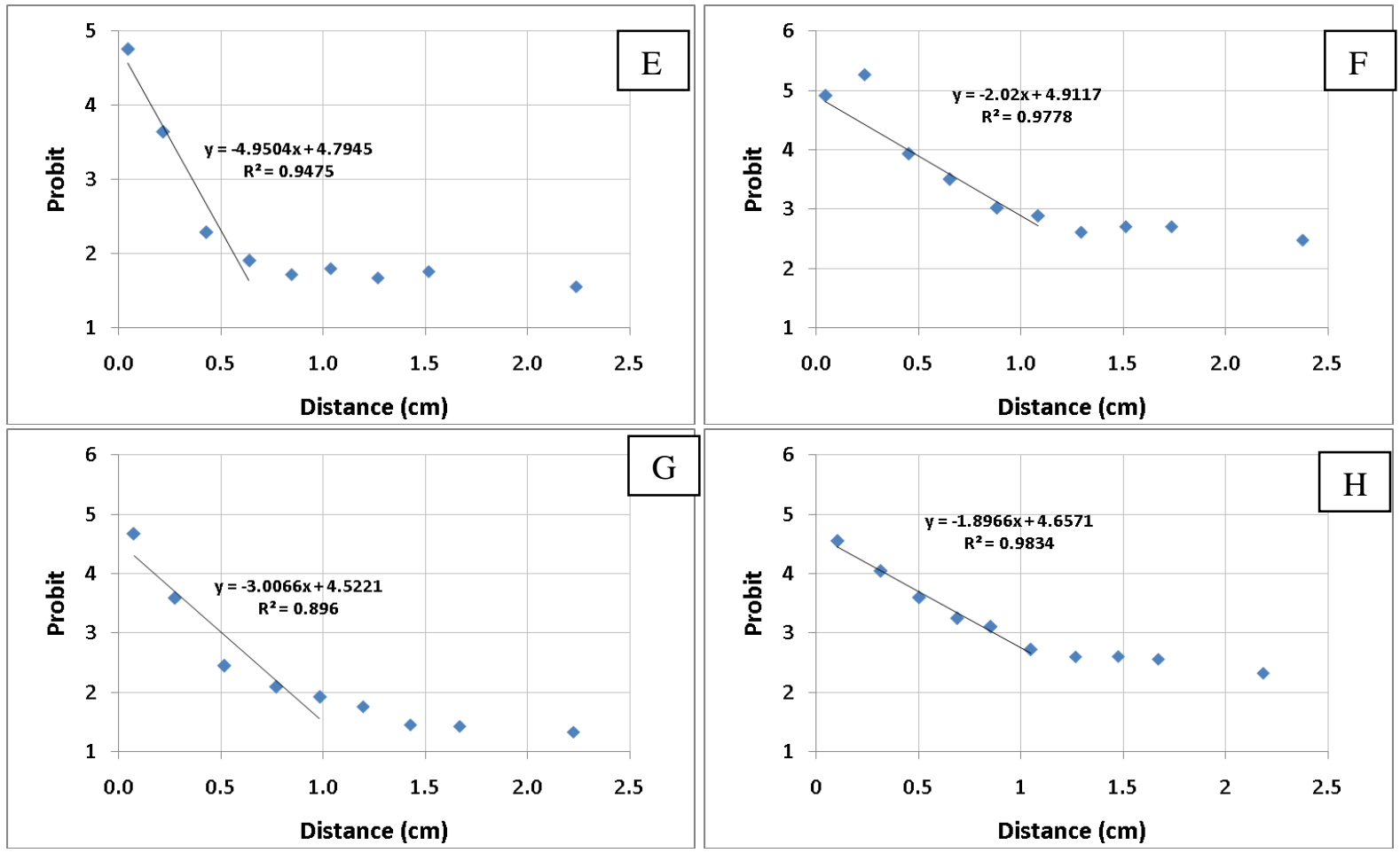

Figure 2.7. Probit Analysis of FY 2010 Tc Cores E) Tc-C-10-5-8-107, F) Tc-C-10-5-8-108, G) Tc-C-105-12-110, H) Tc-C-10-5-12-111 
Table 2.8. Diffusivity Analysis of FY 2010 Tc Cores

\begin{tabular}{cccc}
\hline Core ID & Carbonation & Fe (wt \%) & $\begin{array}{c}\text { Tc Diffusivity } \\
\left(\mathrm{cm}^{2} / \mathrm{s}\right)\end{array}$ \\
\hline Tc-C-10-5-0-101 & $\mathrm{N}$ & 0 & $1.08 \times 10^{-10}$ \\
Tc-C-10-5-0-102 & $\mathrm{Y}$ & 0 & $1.35 \times 10^{-10}$ \\
Tc-C-10-5-4-105 & $\mathrm{N}$ & 4 & $2.07 \times 10^{-10}$ \\
Tc-C-10-5-4-106 & $\mathrm{Y}$ & 4 & $3.55 \times 10^{-10}$ \\
Tc-C-10-5-8-107 & $\mathrm{N}$ & 8 & $3.10 \times 10^{-11}$ \\
Tc-C-10-5-8-108 & $\mathrm{Y}$ & 8 & $1.86 \times 10^{-10}$ \\
Tc-C-10-5-12-110 & $\mathrm{N}$ & 12 & $8.41 \times 10^{-11}$ \\
Tc-C-10-5-12-111 & $\mathrm{Y}$ & 12 & $2.11 \times 10^{-10}$ \\
\hline
\end{tabular}





\subsection{Pressurized Unsaturated Flow (PUF) Tests Selected Concrete Waste Forms to Assess the Long-term Stability under Hanford Vadose Zone Conditions}

In dynamic systems, the long-term stability of materials is controlled by solubility and the rate of dissolution. Under highly advective conditions where the rate of transport is greater than the solubility rate, the stability of the material is controlled by dissolution kinetics. Alternatively, in low to moderately advective environments, where the solubility is greater than the rate of mass transport, the long-term stability of the material is based on the solubility of the phase. Complex waste forms such as concrete exposed to environmental conditions such as the Hanford subsurface may exhibit complex, integrated weathering processes which include dissolution and precipitation of starting and secondary phases. Therefore, in order to accurately predict the long-term stability of concrete waste forms under relevant environmental conditions, the rate of waste form weathering and formation of secondary phases and the identity of relevant secondary phases and their impact on contaminant retention must be known.

Dynamic tests were conducted under unsaturated conditions using the pressurized unsaturated flow (PUF) system (Wierenga and Van Genuchten 1989, McGrail and Martin et al. 1997, McGrail and Martin et al. 1999, Pierce and McGrail et al. 2006). The PUF system allows controlled dynamic changes in water content that simulate the periodic wet-dry cycling experienced in the deep vadose zone and smear zone. Additionally, slight changes in $\mathrm{pH}$, conductivity, and water content that occur during dissolution and precipitation reactions are continuously logged via the PUF system. As such, the PUF system is well suited to conducting unsaturated weathering and precipitation experiments (McGrail and Martin et al. 1997, McGrail and Martin et al. 1999, Pierce and McGrail et al. 2006) (Figure 3.1).

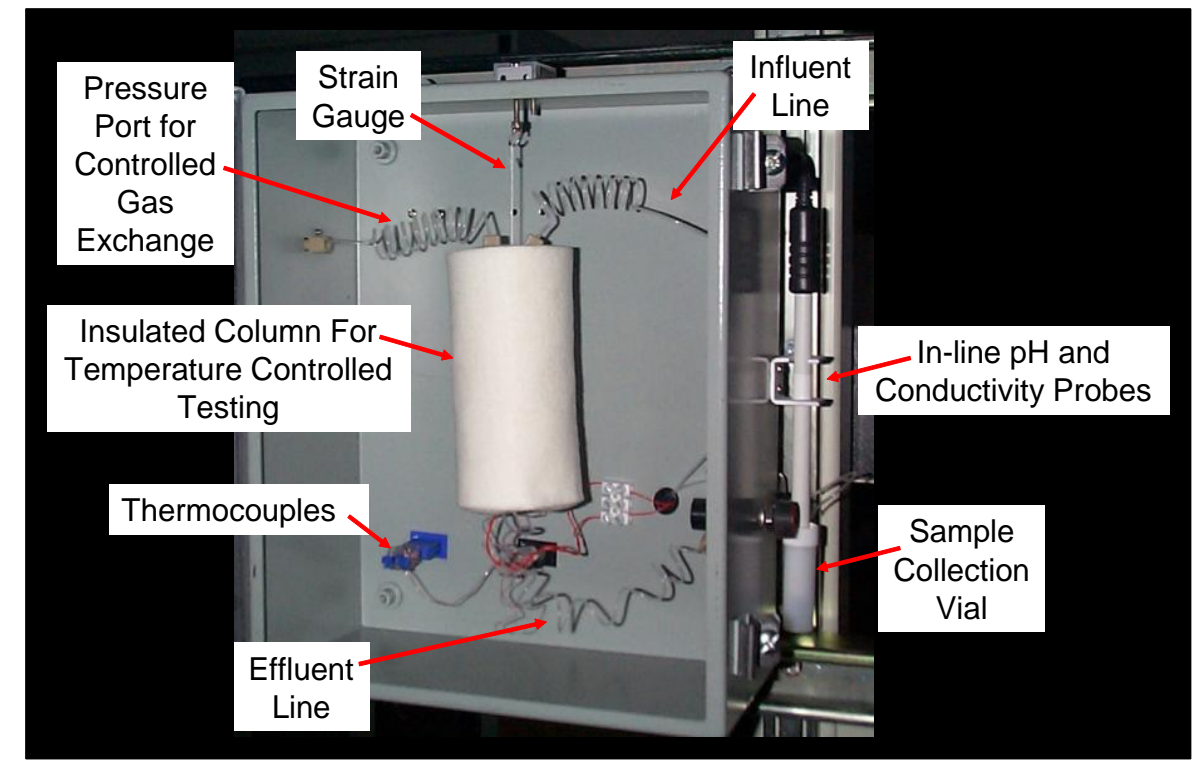

Figure 3.1. Photo of PUF Column Assembly 
The PUF system, which is similar to a Wierenga column (McGrail and Martin et al. 1997, McGrail and Martin et al. 1999), consists of a polyetheretherketone column $(r=0.96 \mathrm{~cm}, L=7.62 \mathrm{~cm})$ with a porous titanium plate; it has a nominal pore size of $0.2 \mu \mathrm{m}$ and is sealed in the bottom of the column. Once the porous titanium plate is water saturated, water, but not air, is allowed to flow through the $0.2-\mu \mathrm{m}$ pores, as long as the applied pressure differential does not exceed the air entry relief pressure, referred to as the bubble pressure of the Ti-plate. If the pressure differential is exceeded, air will escape through the plate and compromise the capability to maintain unsaturated flow conditions in the column (McGrail and Martin et al. 1997, McGrail and Martin et al. 1999). The PUF test computer control system runs LabVIEW ${ }^{\mathrm{TM}}$ (National Instruments Corporation) software for logging test data from several thermocouples, pressure sensors, and inline sensors that measure effluent $\mathrm{pH}$ and conductivity, and from an electronic strain gauge that measures column weight to accurately track water mass balance and saturation level. The column also includes a PUF port, which is an electronically actuated valve that periodically vents the column gases. The purpose of column venting is to prevent reduction in the partial pressure of important gases, especially $\mathrm{O}_{2}$ and $\mathrm{CO}_{2}$, which may be consumed in a variety of chemical reactions.

Three columns were packed with concrete coupons and quartz sand, to be run at 23,60 , and $90^{\circ} \mathrm{C}$. The columns were saturated from the bottom using vacuum pressure and a flow rate of $10 \mathrm{~mL} / \mathrm{hr}$. The process of fully saturating the column and reducing the water content to the desired level minimizes preferential flow paths and hysteresis verifies the most consistent, uniform attainment of water content within a series of unsaturated columns. It also affords a consistent method for establishing unsaturated conditions. Sediment bulk density, $\rho_{b}\left(\mathrm{~g} \mathrm{~cm}^{-3}\right)$, and volumetric water content, $\theta\left(\mathrm{cm} \mathrm{cm}^{-3}\right)$, were determined from the mass of the sediment and water. The percent saturation was calculated from the ratio of the volumetric water content to the total porosity, $\phi$, which was calculated from the bulk density and particle density, $\rho_{p}\left(\mathrm{~g} \mathrm{~cm}^{3}\right)$.

Flow was initiated with Hanford groundwater at a rate of $2 \mathrm{~mL} /$ day under a pressure of $2 \mathrm{psi}$. All effluent solutions were monitored for $\mathrm{pH}$ with in-line sensors. Prior to starting the experiments, the inline $\mathrm{pH}$ probe was calibrated with National Bureau of Standards $\mathrm{pH}$ buffers ( $\mathrm{pH} 7.00,10.00$, or 12.00 at $25^{\circ} \mathrm{C}$ ). Precision of $\mathrm{pH}$ measurement was $\pm 0.02 \mathrm{pH}$ units. Concentrations of $\mathrm{Ca}, \mathrm{K}, \mathrm{Na}, \mathrm{Re}$, and $\mathrm{Si}$ in the effluent solution samples were monitored with ICP-OES methods. After passing through the $0.2-\mu \mathrm{m} \mathrm{Ti}$ porous plate and the inline sensors, aliquots of the effluent solutions were acidified with ultra-high-purity concentrated $\mathrm{HNO}_{3}$ and analyzed using ICP-OES methods.

The reactivity of the concrete coupons in the 60 and $90^{\circ} \mathrm{C}$ columns was sufficiently rapid to occlude the flow path within a day after initiation of the experiment. Results to date for the PUF column containing concrete monoliths in quartz sand at $23^{\circ} \mathrm{C}$ are presented in Figure 3.2. Results from the analyses of effluent samples of $\mathrm{Ca}, \mathrm{Si}$, and $\mathrm{Na}$ are relatively constant over the duration of the experiment thus far. Concentrations of Re initiated at $3.32 \times 10^{7} \mu \mathrm{g} / \mathrm{L}$ and steadily declined to $3.6 \times 10^{3} \mu \mathrm{g} / \mathrm{L}$ over 60 days.

Upon termination of the column tests, secondary phase formation will be assessed using XRD and SEM to develop a mechanistic understanding of the formation and/or transformation and identity of resulting phase(s) during weathering under environmentally relevant conditions. 

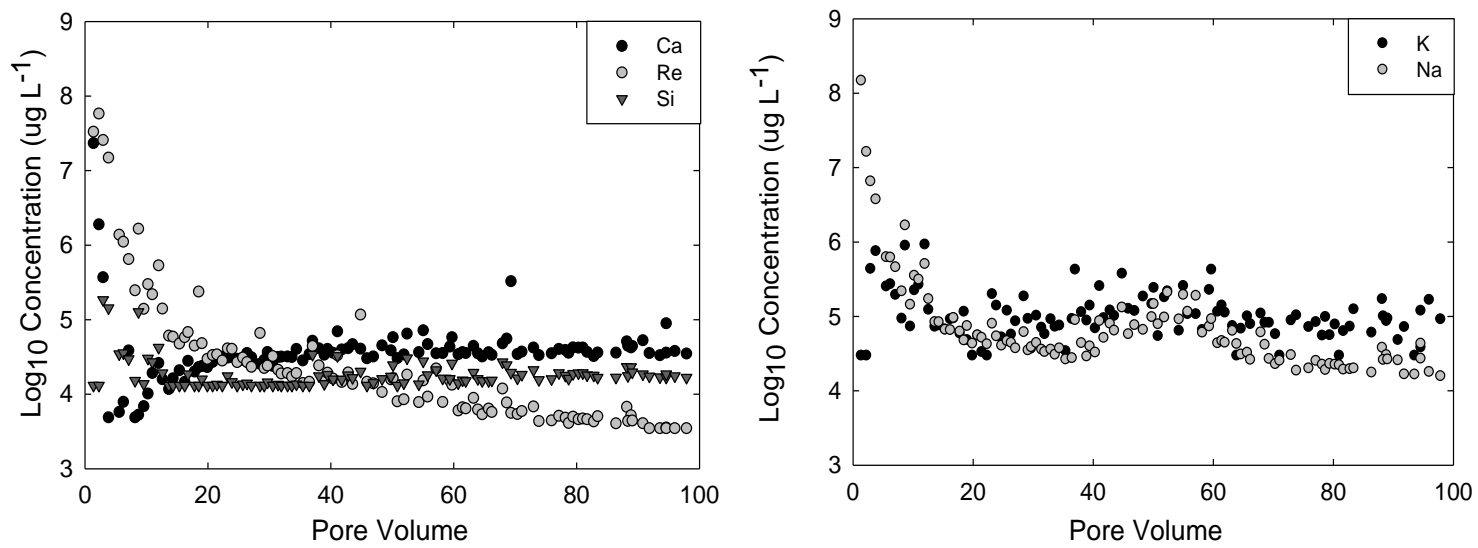

Figure 3.2. $\log _{10}$ Concentration of Elements, in $\mu \mathrm{g} / \mathrm{L}$, Released From the Concrete Coupon PUF Column Measured in the Effluent Solutions As a Function of Pore Volume 



\subsection{Solubility of Uranium in Concrete Waste Forms and Hanford Vadose Zone Sediments}

A study was initiated during FY2004 to better understand the reactivity of limited solubility U(VI)bearing compounds in Portland cement grout specimens. The U(VI) nitrate-spiked specimens were aged for various time spans ranging from 2 weeks to 1 year. A scanning electron microscopy/energy dispersive spectrometer (SEM-EDS) was used to identify the uranium-bearing compounds that formed in the specimens. The uranium phases were identified to be those of soddyite, becquerelite, uranophane, and autunite. A literature search conducted in FY2004 revealed that reliable thermochemical data are not available for these phases under conditions present in concrete waste forms. In FY2006, we developed synthetic routes for the precipitation of pure uranium soddyite, becquerelite, and uranophane. In FY2007 and FY2008, a series of solubility tests were initiated to better understand uranium reactivity in concrete waste forms and improve the ability of performance assessment models to predict the release of uranium from waste form concrete. Equilibrium solubility measurements were conducted under concrete pore water conditions for the identified uranium-solid phases (soddyite, becquerelite, uranophane, and autunite) present in weathered concrete waste forms. Preliminary confirmation of secondary phases was conducted using SEM-EDS in FY2008. Results suggested the formation of 1) a calcium-uranium oxide from the reaction of becquerelite, 2) uranophane group minerals from the reaction of soddyite, and 3) mixed sodium-calcium uranium phosphate secondary phases from the reaction of autunite in simulated Portland cement-equilibrated pore water.

In FY2009, thermodynamic geochemical modeling of pore water compositions in equilibrium with the uranium phases was conducted to evaluate the aqueous speciation and saturation state of the effluent solutions with respect to key minerals, solids, and aqueous phases. Geochemical modeling results support preliminary spectroscopic results which suggested the formation of 1) a calcium-uranium oxide from the reaction of becquerelite; 2) uranophane/becquerelite group minerals from the reaction of soddyite; and 3) mixed sodium-calcium uranium phosphate secondary phases from the reaction of autunite in simulated Portland cement-equilibrated pore water. The results further suggested that 1) the release of uranium from the degradation of uranium oxyhydroxides will be controlled by the formation of secondary uranium oxides; 2) regardless of the replacement of soddyite by uranophane, uranyl-silicate phases will persist within concrete waste forms; and 3) the release of uranium from the degradation of uranium-phosphate phases will be controlled by the formation of secondary uranyl-phosphate phases.

In FY2010, detailed EXAFS spectroscopic analyses were completed to provide further information supporting the preliminary identifications of uranium phases to better understand the long-term stability and controls of uranium provided by concrete waste forms. Additionally, the speciation and thermodynamic solubility data describing the release of uranium from concrete waste forms and within vadose zone environments and a range of steady state concentration values for concretedominated and natural soil conditions will be defined as recommended input for waste form release calculations in future PA analyses. 


\subsection{Extended X-Ray Absorption Fine Structure Spectroscopy}

Although SEM-EDS and X-ray diffraction (XRD) provide preliminary information regarding the possible secondary phases that form and may control uranium mobility in concrete pore fluids, they provide limited structural and speciation information on phases present at $<5 \mathrm{wt} \%$. Therefore, in order to precisely understand the mechanisms of transformation and identity of uranium phases controlling the long-term mobility of uranium in concrete waste forms, EXAFS analysis was conducted on pristine uranium phases, and the uranium phases reacted with simulated concrete pore fluids.

Concrete pore water composition is listed in Table 4.1.

Table 4.1. Chemical Composition of Portland Cement-Equilibrated Waters (From Ewart et al. 1992)

\begin{tabular}{lccccccccc}
\hline \multicolumn{1}{c}{ Cement } & $\mathrm{Ca}$ & $\mathrm{Na}$ & $\mathrm{Mg}$ & $\mathrm{Cl}$ & $\mathrm{SO}_{4}{ }^{2-}$ & $\mathrm{CO}_{3}{ }^{2-}$ & $\mathrm{Al}$ & $\mathrm{Si}$ & $\mathrm{pH}$ \\
\hline SRPC/L & $6.7 \mathrm{E}-3$ & $2 \mathrm{E}-4$ & $<8 \mathrm{E}-8$ & $4 \mathrm{E}-5$ & $4 \mathrm{E}-5$ & $8.5 \mathrm{E}-5$ & $7.4 \mathrm{E}-4$ & $5.3 \mathrm{E}-6$ & 12.5 \\
9:1 BFS/OPC & $6.8 \mathrm{E}-3$ & $3.4 \mathrm{E}-3$ & $4.7 \mathrm{E}-7$ & $6.2 \mathrm{E}-5$ & & $1 \mathrm{E}-4$ & $8 \mathrm{E}-5$ & $2.3 \mathrm{E}-5$ & 12.2 \\
OPC/BFS/L & $6.7 \mathrm{E}-3$ & $5 \mathrm{E}-3$ & $<8 \mathrm{E}-7$ & $2.4 \mathrm{E}-3$ & $6 \mathrm{E}-3$ & $2.8 \mathrm{E}-4$ & $9.5 \mathrm{E}-5$ & $7 \mathrm{E}-4$ & 12.1 \\
OPC/L & $2 \mathrm{E}-2$ & $8.3 \mathrm{E}-4$ & $<4 \mathrm{E}-8$ & $9 \mathrm{E}-5$ & $1 \mathrm{E}-5$ & $2 \mathrm{E}-5$ & $1 \mathrm{E}-5$ & & 12 \\
HARWELL & $1 \mathrm{E}-2$ & $5 \mathrm{E}-5$ & $5 \mathrm{E}-6$ & $2 \mathrm{E}-3$ & $3 \mathrm{E}-3$ & $3 \mathrm{E}-5$ & & & 12 \\
\hline
\end{tabular}

Uranium $\mathrm{L}_{\mathrm{III}}$ EXAFS measurements of the samples were conducted at room temperature on the Molecular Environmental Sciences Beamline 11-2 (Bargar, Jr. et al. 2002) at the Stanford Synchrotron Radiation Laboratory (SSRL) using a cryogenically cooled Si (220), $\phi=0^{\circ}$, double-crystal monochromator. Fluorescence-yield data were collected using a high throughput 30-element solid-state Ge detector. A collimating mirror before the monochromator was used for harmonic rejection, with a cutoff of $19.6 \mathrm{keV}$. Yttrium metal foil was mounted between two ionization chambers downstream of the sample for energy calibration; the first inflection point in the yttrium K-edge was set to $17038 \mathrm{eV}$. Background-subtracted $\mathrm{k}^{3}$-weighted EXAFS data were analyzed using the SixPACK (Webb 2004) interface to IFEFFIT (Newville 2001). Data were fit as linear combinations of the $\chi$ data from $\mathrm{k}=3-12$, $\mathrm{k}^{3}$ weighted for the original uranium mineral and potential secondary phase minerals. A suite of model compound combinations were run to determine the best possible fit of the spectra. Combinations of autunite, schoepite, boltwoodite, uranium rich calcite, soddyite, and uranophane were run based on starting mineral, pore water chemistry, and secondary phases suggested from SEM-EDS analysis and geochemical modeling. Samples were down selected for EXAFS analysis due to the limited availability of analysis time at SSRL. Samples were selected based on results from SEM-EDS and geochemical modeling which indicated the formation of secondary phases.

Table 4.2. Results of Linear Combination Fit of Autunite Solubility Tests

\begin{tabular}{cc}
\hline & Autunite \\
\hline HAR_A_3.5M & 0.95 \\
HAR_A_1YR & 0.89 \\
BFS_A_3.5M & 0.84 \\
BFS_A_1YR & 0.85 \\
SRPC_A_3.5M & 0.93 \\
\hline
\end{tabular}




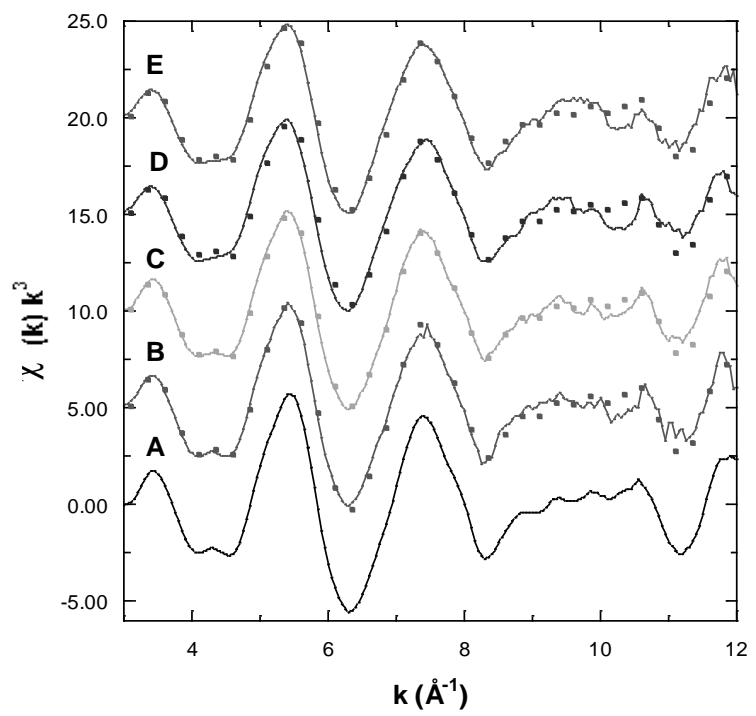

Figure 4.1. EXAFS of 3.5 and 1 Year Autunite Solubility Tests (a) Autunite Mineral, (b) Harwell Reacted Autunite After 3.5 Months (HAR_A_3.5M), (c) Harwell Reacted Autunite After 1 Year (HAR_A_1YR), (d) BFS Reacted Autunite After 3.5 Months (BFS_A_3.5M), and (e) BFS Reacted Autunite After 1 Year. The dots are the best fit to the EXAFS spectra using linear combination of autunite and uranophane mineral.

Figure 4.1 shows EXAFS analysis of autunite minerals in Harwell and OPC/BFS/L pore waters for 3.5 months and 1 year. The spectra indicate the retention of uranium phosphate minerals over the course of 3.5 months and 1 year for both the Harwell and OPC/BFS/L pore waters. The results of linear combination fits for Figure 4.1 are presented in Table 4.2. The fits were well fit using solely autunite. The fits indicate that Harwell reacted autunite was $95 \%$ autunite after 3.5 months and $89 \%$ autunite after 1 year. When fitting EXAFS spectra, a linear combination equaling $100 \%$ is rare. As with all modeling and spectroscopic fitting, there is a degree of uncertainty that results in a less than $100 \%$ fit. Harwell autunite reacted for 3.5 months is well fit as a 95\% linear combination fit for autunite. Harwell autunite reacted for 1 year is well fit with an $89 \%$ linear combination. This indicates the material is predominately autunite; the exact composition did not fit the model compounds. It is possible that the low percentage of the fit is due to a change in cation (from $\mathrm{Ca}$ to $\mathrm{Na}$ or $\mathrm{Mg}$ ). The $\mathrm{OPC} / \mathrm{BFS} / \mathrm{L}$ reacted autunite was $84 \%$ autunite after 3.5 months and $85 \%$ autunite after 1 year. As above, the best fit spectra consisted of solely autunite.

Figure 4.2 shows the EXAFS spectra for autunite reacted for 3.5 months in Harwell, OPC/BFS/L, and SRPC pore waters. As in Figure 4.1, the EXAFS spectra indicate that after 3.5 months in the different concrete pore waters, the autunite was either unreactive or transformed to another uranium phosphate phase. Table 4.2 gives the results of linear combination fits from the 3.5 month reacted autunite solubility experiments. The autunite reacted in SRPC pore water for 3.5 months was best fit as $95 \%$ autunite.

Uranium phosphate minerals are structurally very similar which affords spectroscopic analyses that are relatively indistinguishable from one another (Catalano and Jr. 2004). Because autunite was the known starting phase within these experiments, the reacted minerals were fit using autunite as a model mineral for comparison. However, it cannot be ascertained from EXAFS data alone whether the autunite solubility tests were stable over the duration of the test or if secondary uranium-phosphate phases were also formed. SEM-EDS analysis supported the formation of secondary phase(s) on the autunite reacted 


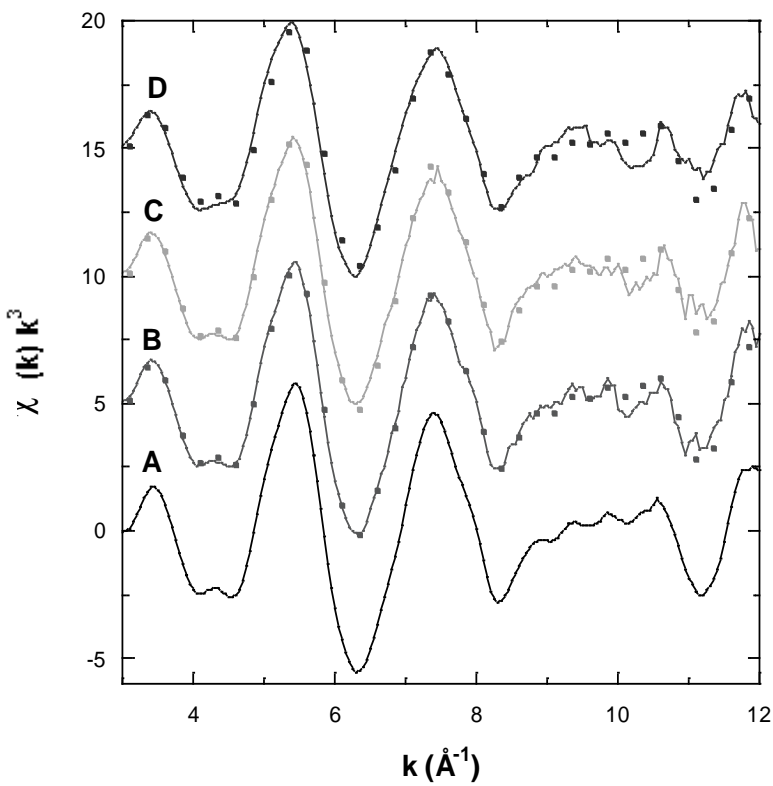

Figure 4.2. EXAFS of 3.5 Month Reacted Autunite Solubility Tests (a) Autunite Mineral, (b) SRPC Reacted Autunite After 3.5 Months, (c) Harwell Reacted Autunite After 3.5 Months, and (d) BFS Reacted Autunite After 3.5 Months. The dots are the best fit to the EXAFS spectra using linear combination of autunite.

samples, with mixed sodium-calcium uranium phosphates tentatively identified through EDS analysis. Geochemical modeling performed in FY2009 using element concentrations indicated a mixed sodiumcalcium uranium phosphate secondary phase in Portland cement pore water. The combination of SEM imaging, which showed secondary phase formation; EDS analysis and geochemical modeling, which predicted the formation of uranium phosphate secondary phases; and EXAFS linear combination fits, which indicated the reacted autunite sample contained only uranium phosphates, support the hypothesis that in contact with Portland cement pore waters, autunite undergoes a dissolution-precipitation reaction which results in the formation of uranium phosphate species. From these results, the ability of concrete waste forms to retain uranium is high, due to the re-precipitation of high stability phosphate phases. Among the paragenetic sequence of uranium, phosphate species are among the most stable.

Figure 4.3 and Table 4.3 show the results from EXAFS analysis of soddyite mineral solubility tests. Provided in Figure 4.3 are the EXAFS spectra of soddyite and uranophane model compounds, Harwell reacted soddyite after 3.5 months, OPC/L reacted soddyite after 3.5 months, and OPC/BFS/L reacted soddyite after 3.5 months. Based on the sharpening of the peak between $\mathrm{k} 7$ and 8 , the introduction of the uranophane hump around $\mathrm{k} 9.2$, and the minimization of the soddyite peak at $\mathrm{k}$ 10, the EXAFS spectra suggest that soddyite changes to a mixture of soddyite uranophane across the three different pore waters (Harwell, OPC/L, and OPC/BFS/L). Table 4.3 lists the results from the linear combination fits. The spectra were well fit using a mixture of soddyite and uranophane. For the Harwell reacted soddyite, the best fit was 59\% soddyite and 33\% uranophane; for OPC/L it was 55\% soddyite and 33\% uranophane and for $\mathrm{OPC} / \mathrm{BFS} / \mathrm{L}$ it was $19 \%$ soddyite and $72 \%$ uranophane. These results indicate that irrespective of pore water silicate concentration, soddyite minerals transform into a more stable uranophane group mineral, which will further control the stability of these minerals within concrete pore waters. These results correspond to geochemical modeling and SEM-EDS data provided in the FY2008 and FY2009 reports that suggested the formation of uranophane/becquerelite group mineral phases for the soddyite solubility tests. 


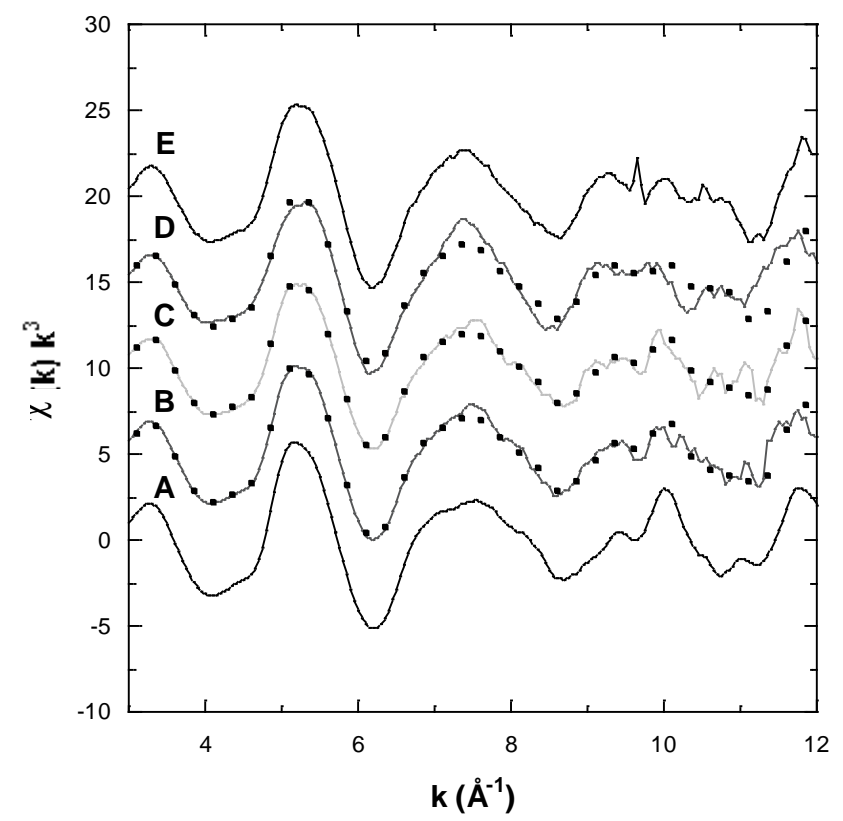

Figure 4.3. EXAFS of 3.5 Month Reacted Soddyite Solubility Tests (a) Soddyite Mineral, (b) Harwell Reacted Soddyite After 3.5 Months, (c) OPC/L Reacted Soddyite After 3.5 Months, (d) BFS Reacted Soddyite After 3.5 Months, and (e) Uranophane Mineral. The dots are the best fit to the EXAFS spectra using linear combination of soddyite and uranophane.

Table 4.3. Results of Linear Combination Fit of Soddyite Solubility Tests

\begin{tabular}{lcc}
\hline & Soddyite & Uranophane \\
\hline HAR_S_3.5M & 0.59 & 0.33 \\
OPC_S_3.5M & 0.55 & 0.33 \\
BFS_S_3.5M & 0.19 & 0.72 \\
\hline
\end{tabular}

EXAFS analysis of becquerelite concrete solubility tests was performed. However, a suitable model compound for becquerelite was not available and linear combination fits were unable to be performed. Additionally, EXAFS analysis of uranophane concrete solubility tests was not performed due to the evaluation of the uranophane tests with SEM-EDS and geochemical modeling which did not suggest the formation of secondary phases.

\subsection{Recommendations on Solubility of Uranium in Concrete Waste Forms and Hanford Vadose Zone Sediments}

The speciation and thermodynamic solubility data describing the release of uranium from concrete waste forms and within vadose zone environments and a range of steady-state concentration values for concrete-dominated and natural soil conditions will be defined as recommended input for waste form release calculations in future PA analyses. Completion and submission of this report will be in February 2011. 



\subsection{Comprehensive Report on All the Diffusion Work Conducted Over the Project Life Period}

During the project life time, the diffusion of radionuclides has been quantified from concrete into soil and from spiked soil into concrete as a function of the following environmental and concrete waste form parameters:

- Radionuclide Concentration

- Diffusion Time

- Carbonation of Concrete Waste Forms

- Experimental Methods of Carbonation

- Concrete Waste Form Microcracking

- Fracturing of Concrete Waste Forms

- Iron Content in Concrete Waste Forms

- Soil Moisture Content

A report is being prepared to include a compilation of all diffusion data, analysis, and a summary that will provide a basis to predict diffusivity of I and Tc into and out of waste forms and the encasing vadose zone soils. In addition, the results of the probit analyses and quantification of diffusion coefficients are being utilized to calculate the diffusion of I, Re, and Tc through 6 inches of concrete. Completion and submission of this report will be in February 2011. 



\subsection{References}

Academies, N. 2009. Advice on the Department of Energy's Cleanup Technology Roadmap: Gaps and Bridges. The National Academies.

Al-Khayat, H., and M.N. Haque et al. 2002. "Concrete carbonation in arid climate." Materials and Structures 35: 421-426.

ANSI. 1986. Measurement of the leachability of solidified low-level radioactive wastes short-term test procedure. Chicago, American Nuclear Society.

Bargar, J.R. and G.E. Brown, Jr. et al. 2002. "A new hard X-ray XAFS spectroscopy facility for environmental samples, including actinides, at the Stanford Synchrotron Radiation Laboratory."

Catalano, J.G. and G.E. Brown, Jr. 2004. "Analysis of uranyl-bearing phases by EXAFS spectroscopy: Interferences, multiple scattering, accuracy of structural parameters, and spectral differences." American Mineralogist 89: 1004-1021.

Crane, P.J. and H.L. Benny, et al. 1992. Physical modeling of contaminant diffusion from a cementious waste form. Richland, Westinghouse Hanford Company: 1-11.

Crank, J. 1975. The Mathematics of Diffusion. Oxford, Clarendon Press.

Finney, D.J. 1971. Probit Analysis. Cambridge, Cambridge University Press.

Garrabrants, A.C. and D.S. Kosson. 2003. "Modeling moisture transport from a Portland cement-based material during storage in reactive and inert atmospheres." Drying Technology 21(5): 775-805.

Garrabrants, A.C. and F. Sanchez et al. 2002. "The effect of storage in an inert atmosphere on the release of inorganic constituents during intermittent wetting of a cement-based material." Journal of Hazardous Materials B91: 159-185.

Garrabrants, A.C. and F. Sanchez et al. 2004. "Changes in constituent equilibrium leaching and pore water characteristics of a Portland cement mortar as a result of carbonation." Waste Management 24: 1936.

Gervais, C. and A.C. Garrabrants et al. 2004. "The effects of carbonation and drying during intermittent leaching on the release of inorganic constituents from a cement-based matrix." Cement and Concrete Research 34: 119-131.

Mann FM, RJ Puigh II, SH Finfrock, J Freeman, E.J., R Khaleel, DH Bacon, MP Bergeron, PB McGrail, and SK Wurstner. 2001. Hanford Immobilized Low-Activity Waste Performance Assessment: 2001 Version, DOE/ORP-2000-24, Rev. B, Pacific Northwest National Laboratory, Richland, Washington.

Martin PF, RJ Serne, VL Legore, and CW Lindenmeier. 1994. Status Report on Ionic Diffusion through Asphalt, HGTP-93-0602-01, Pacific Northwest National Laboratory, Richland, Washington. 
Mattigod, S.V. and G. A. Whyatt et al. 2001. Diffusion and leaching of selected radionuclides (Iodine129, Technetium-99, and Uranium) through Category 3 waste encasement concrete and soil fill material. PNNL-13639, Richland, Washington.

McGrail, B.P. and P.F.C. Martin et al. 1997. Accelerated testing of waste forms using a novel Pressurized Unsaturated Flow (PUF) method. Materials Research Society Symposium Proceedings.

McGrail, B.P. and P.F.C. Martin et al. 1999. Method and apparatus for measuring coupled flow, transport, and reaction processes under liquid unsaturated flow conditions. Battelle Memorial Institute.

Newville, M. 2001. "IFEFFIT: interactive XAFS analysis and FEFF fitting." Journal of Synchrotron Radiation 8: 322-324.

Pierce, E.M., and B.P. McGrail, et al. 2006. "The Accelerated Weathering of a Radioactive LowActivity Waste Glass Under Hydraulically Unsaturated Conditions: Experimental Results from a Pressurized Unsaturated Flow (PUF) Test." Nuclear Technology 155(2): 149-155.

Proceedings of the Euroconference and NEA workshop on Speciation, Techniques and Facilities for Radioactive Materials at Synchrotron Light Sources. NEA/OECD, Paris: 57-68.

Sanchez, F. and A. C. Garrabrants et al. 2003. "Effects of intermittent wetting on concentration profiles and release from a cement-based waste matrix." Environmental Engineering Science 20(2): 135-153.

Sanchez, F.C. and Gervais et al. 2002. "Leaching of inorganic contaminants from cement-based waste materials as a result of carbonation during intermittent wetting." Waste Management 22: 249-260.

Serne RJ, JL Conca, VL LeGore, KJ Cantrell, CW Lindenmeier, JA Campbell, JE Amonette, and MI Wood. 1993. Solid-Waste Leach Characterization and Contaminant-Sediment Interactions, PNL-8889, Vol. 1, Pacific Northwest Laboratory, Richland, Washington.

Serne, R.J. and R.O. Lokken et al. 1992. "Characterization of Grouted LLW to Support Performance Assessment." Waste Management 12: 271-287.

Serne RJ, WJ Martin, and VL LeGore. 1995. Leach Test of Cladding Removal Waste Grout Using Hanford Groundwater. PNL-10745, Pacific Northwest Laboratory, Richland, Washington.

Serne RJ, WJ Martin, VL LeGore, CW Lindenmeier, SB McLaurine, PFC Martin, and RO Lokken. 1989. Leach Tests on Grouts Made with Actual and Trace Metal-Spiked Synthetic Phosphate/Sulfate Waste. PNL-7121, Pacific Northwest Laboratory, Richland, Washington.

"Specification for Concrete Encasement for Contact-Handled Category 3 Waste" (1998). Waste Management. Unpublished Report.

Webb, S.M. 2005. "Sixpack: A graphical user interface for XAS analysis using IFEFFIT." Physica Scripta: 2005:1011. doi: 10.1238/Physica.Topical.115a01011.

Wierenga, P.J. and M.T. Van Genuchten. 1989. "Solute transport through small and large unsaturated soil columns." Ground water 27(1): 35-42. 
Wood, M.I. and R. Khaleel et al. 1995. "Performance Assessment for the Disposal of Low-Level Waste in the 218-W-5 Burial Ground." Richland, Washington, Westinghouse Hanford Company. 



\section{Distribution}

No. of

Copies

\# Local Distribution

Pacific Northwest National Laboratory

SV Mattigod

CC Bovaird

K3-62

DM Wellman

K3-62

MI Wood

K3-62

H8-51

Distr.1 



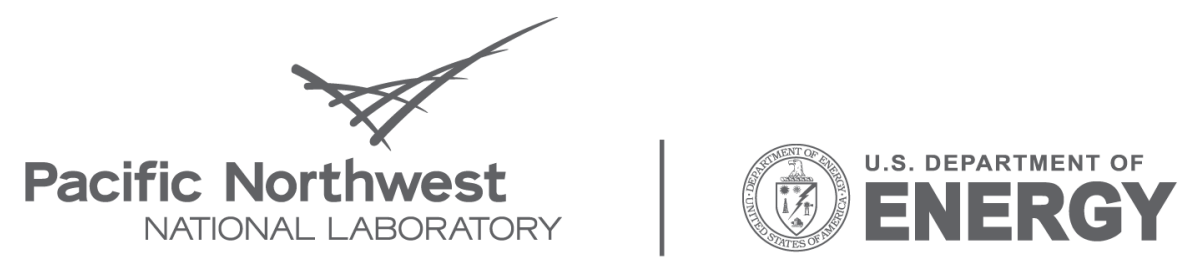

Proudly Operated by Battelle Since 1965

902 Battelle Boulevard

P.O. Box 999

Richland, WA 99352

1-888-375-PNNL (7665)

www.pnl.gov 